\title{
Ethnomathematics Activities: Reflections from the Design and Implementation Process
}

\author{
Özkan Ergene ${ }^{\mathrm{a}}$, Büşra Çaylan Ergene ${ }^{\mathrm{b}}$ and Esin Zelal Yazıci ${ }^{\mathrm{c}}$ \\ ${ }^{a}$ Sakarya University, Faculty of Education, Sakarya/Turkey (ORCID: 0000-0001-5119-2813) \\ ${ }^{\mathbf{b}}$ Sakarya University, Faculty of Education, Sakarya/Turkey (ORCID: 0000-0002-5567-6791) \\ ${ }^{\mathbf{c}}$ Marmara University, Institute of Educational Sciences, İstanbul/Turkey (ORCID: 0000-0003-2004-2286)
}

Article History: Received: 13 February 2020; Accepted: 5 June 2020; Published online: 27 August 2020

\begin{abstract}
Ethnomathematics is a field of mathematical ideas and activities that are embedded in the cultural contexts of societies. The present study aimed to examine the ethnomathematics activities designed by pre-service mathematics teachers in terms of the pre-service teacher variable, the implementation of the designed activities in the classroom environment in terms of the pre-service, the in-service teachers and student variables and to determine pre-service and in-service teachers' awareness of ethnomathematics, their prior learning of ethnomathematics and their use of ethnomathematics in professional life. In this qualitative research study, the multiple case study was utilized. The participants of the study were 28 pre-service teachers, 71 students and 2 in-service teachers. The data collection tools of the study were the activities designed by the preservice teachers, the questionnaires administered to the in-service teachers and students, the semi-structured interviews held with the pre-service teachers and the researchers' field notes. The data collection process of the research was carried out in three phases consisting of preparation, design and implementation. The designed activities were analyzed in terms of the curriculum (related topics, prior learning) and use of material, and the data obtained from the questionnaires were analyzed by creating codes and categories according to the characteristics of the questions in the questionnaire. The fact that there are too many geometric elements in the Turkish culture, a limited number of studies in the field of ethnomathematics, an insufficient number of books, and individual characteristics of the pre-service teachers have influenced the design process of the activity. It was revealed that the activity implementation process had some advantages, such as increasing students' interest in the lesson, making the class enjoyable, and enabling the teaching of cultural elements, as well as a disadvantage in terms of classroom management. The design of the ethnomathematics activities and their implementation in the classroom environment increased the pre-service and in-service teachers' awareness of the relationship between culture and mathematics. In the questionnaires, pre-service and in-service teachers stated that they wanted to use ethnomathematics activities in their professional lives. Similarly, the students indicated that they wanted to do similar activities related to culture in mathematics lessons.
\end{abstract}

Keywords: Ethnomathematics, culture and mathematics, activity design, activity implementation

DOI: $10.16949 /$ turkbilmat.688780

Öz: Toplumların kültürel bağlamlarında gömülü olan matematiksel düşüncelerin ve faaliyetlerin incelendiği alan etnomatematik olarak adlandırılmaktadır. Bu araştırmada, ilköğretim matematik öğretmen adayları tarafından tasarlanan etnomatematik etkinliklerin öğretmen adayı boyutunda, tasarlanan etkinliklerin sınıf ortamında uygulanmasının öğretmen adayı, öğrenci ve öğretmen boyutlarında incelenmesi ve öğretmen adayları ve öğretmenlerin etnomatematiğe yönelik farkındalık, önceki öğrenme ve mesleki hayatta kullanım durumlarının belirlenmesi amaçlanmıștır. Nitel araştırma yöntemi ile yürütülen araştırmanın deseni çoklu durum çalışması olarak belirlenmiştir. Araştırmanın çalışma grubunda 28 öğretmen adayı, 71 öğrenci ve 2 öğretmen yer almaktadır. Araştırmanın veri toplama araçlarını öğretmen adaylarının tasarladığ etkinlikler, öğretmen adayları, öğretmenler ve öğrencilere uygulanan yazılı görüs formları, öğretmen adayları ile yapılan yarı yapılandırılmış görüşmeler ve araştırmacı alan notları oluşturmaktadır. Araştırmanın veri toplama süreci hazırlık, tasarım ve uygulama olmak üzere üç aşamada gerçekleştirilmiştir. Tasarlanan etkinlikler öğretim programı (ilgili konular, önceki öğrenmeler) ve materyal kullanımı bağlamlarında, görüşme formlarından elde edilen veriler ise formlarda yer alan soruların özelliklerine göre kodlar ve kategoriler oluşturularak analiz edilmiștir. Kültürümüzde geometrik ögelerin fazla olması, etnomatematik alanında yapılan çalışmaların azlığı, kaynak kitap yetersizliği ve öğretmen adaylarının bireysel özellikleri etkinlik tasarlama sürecine etki etmiştir. Etkinlik uygulanma sürecinin derse yönelik ilginin artması, dersin eğlenceli geçmesi, kültürel ögelerin ögretimi gibi avantajlarının yanında sınıf hâkimiyeti noktasında dezavantaj oluşturduğu belirlenmiștir. Etnomatematik etkinliklerinin tasarlanması ve sınıf ortamında uygulanması öğretmenlerin ve öğretmen adaylarının kültür ile matematik ilişkisine yönelik farkındalıklarını artırmıştır. Bununla birlikte öğretmen adayları ve öğretmenler görüş formunda etnomatematik etkinliklerini mesleki hayatlarında kullanmak istediklerini ifade etmişlerdir. Öğrenciler de matematik derslerinde kültürle ilgili bu tarz etkinlikler yapmak istediklerini belirtmişlerdir.

Anahtar Kelimeler: Etnomatematik, kültür ve matematik, etkinlik tasarlama, etkinlik uygulama

Türkçe sürüm için tıklayınız

Corresponding Author: Özkan Ergene (D) email: ozkanergene@sakarya.edu.tr

Citation Information: Ergene, Ö., Çaylan-Ergene, B., \& Yazıcı, E. Z. (2020). Ethnomathematics activities: Reflections from the design and implementation process. Turkish Journal of Computer and Mathematics Education, 11(2), 402-437. 


\section{Introduction}

The question "How did mathematics evolve?" is still being discussed today, and there is still no agreement over the answer to this question. When the history of mathematics is examined, it is seen that philosophy and mathematics are intertwined (Baki, 2014). In addition, mathematics is often considered abstract and only associated with calculations based on formulas and theorems. This thought also ignores the effects of such disciplines as philosophy, culture and value on the emergence of mathematics. However, mathematics did not develop in a glass jar independently of the individual and culture. Mathematics is a system of thought in which culture and values play an important role in its emergence and development (Leitze, 1997; Lim \& Ernest, 1997; Zaslavsky, 1998). In this context, a research field named "ethnomathematics" that deals with the relationship between culture and mathematics emerged. The thought that mathematics developed independently of culture negatively affected the development process of ethnomathematics (Gerdes, 2001).

The term ethnomathematics has been described as methods and techniques (tics) used to learn, understand, explain, and manage the reality (mathema) faced by distinct natural, social, political or cultural (ethno) environments (D'Ambrosio, 2018). Ethnomathematics can also be defined as "the study of mathematical ideas and activities as embedded in their cultural context" (Gerdes, 2001, p.12). In ethnomathematics, every culture develops its own particular mathematical ideas, thoughts and practices (Ascher, 1994; Barton, 1996). Although ethnomathematics intended to reconstruct or unfreeze the mathematical thinking that is hidden or frozen in old techniques, it has become a part of the mathematics used today (Gerdes, 1994). Bishop (1991) identified six mathematical activities of culture including counting, locating, measuring, designing, playing and explaining. In addition, Bishop (1991) argued that mathematical concepts and relationships emerged with these activities. For example, he identified numbers, number patterns and number systems under counting; coordinates and geometric place under locating; properties, shape and similarity of objects under designing. In the initial studies conducted in the field of ethnomathematics, the mathematical activities performed by illiterate primitive individuals were addressed (Francois \& Kerkhove, 2010). Later, many mathematical concepts or areas such as numbers, pattern, fractal, probability and algebra were the subjects of ethnomathematics. Within this process, with studies conducted by researchers, such as D'Ambrosio, Ascher and Gerdes, ethnomathematics which took into consideration the relationship between culture and mathematics in detail has taken its present form.

In the field of mathematics education, research studies on ethnomathematics have been conducted by using quantitative and qualitative research methods with participants in all age from preschool level to higher education level. In these studies, it was found that ethnomathematics increases achievement (Magallanes, 2003), improves mathematical understanding (Widada, Herewaty, \& Lubis, 2018), develops mathematical thinking skills (Iluno \& Taylor, 2013; Powell \& Temple, 2001) and a positive attitude towards mathematics (Aktuna, 2013; Kara, 2009). Moreover, ethnomathematics helps students see that mathematics is not culture-free and enables them to gain cultural awareness (Bishop, 1991; Zaslavsky, 1998).

It is important to become aware of the fact that mathematics emerged to meet the needs of people and it is used to meet needs in everyday life. Making sense of the relationship between mathematics and culture will contribute positively to this awareness process. Indeed, cultural values, cultural knowledge and cultural thinking processes of an individual and the mathematical knowledge and mathematical thinking acquired within the scope of school mathematics complement each other (Güreş, 2019). For this reason, it is important to include practices related to ethnomathematics that can reveal the relationship between culture and mathematics in mathematics lessons. However, it was seen that mathematics teachers were incompetent in integrating the relationship between mathematics and culture into the classroom environment (Lewis, 2016). This incompetence negatively affects students' mathematics achievement, leads them to think that there is no interaction between culture and mathematics and prevents them from establishing a role model relationship (d'Entremont, 2015; Krummel, 2013). It was also observed that teachers did not have sufficient knowledge of ethnomathematics due to lack of experience, material and pedagogy. For this reason, it has been recommended that ethnomathematics should be embedded into the mathematics curriculum (Kang, 1992).

In Turkey, the Turkish Qualifications Framework within the curricula of educational programs requires students to have "cultural awareness and expression" (Ministry of National Education [MoNE], 2018) and this can be developed with the help of ethnomathematics. Thus, the teacher training programs were updated by the Higher Education Council [HEC] in 2018, and a course titled "Culture and Mathematics" was incorporated into the Elementary Mathematics Education Program. The content of this course, which is a departmental elective course, includes topics such as the relationship between mathematics and culture, the basic principles of research in the field of ethnomathematics, the importance of including ethnomathematics studies in classroom practices, and designing in-class mathematics activities for different cultural contexts. When the purpose and content of the Culture and Mathematics course is considered, it is seen that there is an emphasis on the meaning, importance and use of ethnomathematics in classrooms. 
When the literature is reviewed, it is observed that although there are studies in the field of ethnomathematics at the international level, the number of studies conducted in Turkey is very small (Güreş, 2019). Studies conducted in Turkey have been limited to several postgraduate theses, articles, papers and one translation book. These sources include studies which address how students conceptualize mathematical concepts and associate them with the lesson content enriched with elements of their own culture (Aktuna, 2013), and how students interpret this process and participate in activities (Sevgi, 2019; Y1lmaz, Öztürk, \& Kanbolat, 2012). Moreover, in one study, the mathematical thinking of students with different cultural values were examined with a qualitative paradigm (Güreş, 2019). There are also experimental studies in which the effects of ethnomathematics on academic achievement and attitude towards mathematics were examined (Kara, 2009). With the small number of research studies conducted in Turkey related to ethnomathematics, which is accepted as a relatively new research field, it can be said that the relationship between the Turkish culture and mathematics education has not been sufficiently revealed.

Thus, the purpose of the present study was to examine the ethnomathematics activities designed by preservice mathematics teachers in terms of the pre-service teacher variable, the implementation of the designed activities in the classroom environment in terms of the pre-service, the in-service teachers and student variables and to determine pre-service and in-service teachers' awareness of ethnomathematics, their prior learning of ethnomathematics and their use of ethnomathematics in professional life. For this purpose, the following research questions were formulated:

- What are the advantages and disadvantages of the design and implementation processes of ethnomathematics activities?

- What is the pre-service and in-service teachers' level of awareness toward ethnomathematics, their prior learning and use of ethnomathematics in professional life?

- What are the students' views regarding use of ethnomathematics activities in mathematics lessons?

By revealing the theoretical and practical reflections of the relationship between mathematics and culture by means of the present research, pre-service and in-service teachers' awareness towards ethnomathematics may increase, which is considered as the strength of the research. In addition, the designed ethnomathematics activities will function as samples for pre-service and in-service mathematics teachers to be used in the classroom. Also, considering the small number of studies in the field of ethnomathematics in Turkey, it is believed that this study may contribute to the ethnomathematics literature.

\subsection{Theoretical framework}

The ethnomathematical approach proposed by D'Ambrosio was used as the theoretical framework. According to this theoretical framework, the most important aim of school mathematics should be to make students aware of the mathematical thinking that exists in the culture they are in, see mathematics as a part of daily life and thus value their culture. It is argued that this awareness and consciousness will lead to the development of other cognitive skills as well (D’Ambrosio \& Rosa, 2017).

The ethnomathematical approach approaches mathematics from a cultural anthropology perspective, questions the relationship between mathematics and culture, and advocates the opposite of the general belief that mathematics is culture-free (Stathopoulou, Kotarinou, \& Appelbaum, 2015). The essence of this approach is to understand how mathematical knowledge is formed, organized and disseminated in different cultural environments (D'Ambrosio, 2007). Students carry the values, norms and concepts they have to the school. Therefore, learning environments should not be considered separately from the culture they are part of (Adam, 2004). Some of the values, norms and concepts that make up the culture of the students are also mathematical (Bishop, 1994). According to the ethnomathematics approach, which proposes that cultural elements should be included in the mathematics curriculum, academic mathematics, which is necessary for individuals to take an active role in the modern world, should be presented with content enriched with mathematical elements existing in students' cultures (D'Ambrosio, 2001). Without creating the perception that mathematics is a culture-free abstract science, it should be set up in a way that enables students to see that mathematics is an important part of their own culture and civilization (Baki, 2014).

\section{Method}

In the present research study, one of the qualitative methods, namely the multiple case research design (Yin, 1994) was utilized. The design of the ethnomathematics activities, the implementation of the designed activities in the classroom, the awareness of pre-service and in-service teachers' toward ethnomathematics, prior learning of ethnomathematics and use of ethnomathematics in professional life were considered as separate cases and these cases were examined in terms of pre-service teachers, in-service teachers and students in detail. 


\subsection{Participants}

Purposeful sampling technique was used in the selection of the participants since the aim was to conduct an in-depth examination of the design and implementation of ethnomathematics activities in the study (Patton, 1990). Participants of the study included 28 pre-service teachers, 71 students and 2 in-service teachers. 22 of the pre-service teachers were taking the "Culture and Mathematics" course ( $3{ }^{\text {rd }}$ term) and 6 of the pre-service teachers were taking the "Teaching Practice I" course $\left(7^{\text {th }}\right.$ term) in the elementary mathematics teacher education program in one of the state universities at the time of the study. The students, who were from two different public middle schools, were in grade 8 at the time of the study. One of the in-service teachers had been working as a mathematics teacher for 5 years and the other for 19 years. In the following parts of the study, the pre-service teachers taking the Culture and Mathematics course are referred to as [DPS] since they designed ethnomathematics activities during the course, while the pre-service teachers taking the Teaching Practice I course are referred to as [IPS] since they implemented ethnomathematics activities, and the in-service teachers with 5 years of teaching experience are referred to as $T_{1}$, while the other in-service teacher is referred to as $\mathrm{T}_{2}$.

\subsection{Data collection tools}

Data collection tools consist of the activities designed by the pre-service teachers, the questionnaires administered to pre-service teachers, in-service teachers and students, and the researchers' field notes. In addition, semi-structured interviews were conducted in order to obtain in-depth information about the responses given to the questions in the questionnaires.

\subsubsection{Activities}

In the Culture and Mathematics course, instructor of which was the first researcher, the pre-service teachers designed ethnomathematics activities that could convey the relationship between mathematics and culture. These activities were reviewed by the pre-service teachers taking the Teaching Practice I course, and after various revisions were made, the activities were ready to implement in the classroom. In the Culture and Mathematics course, 9 activities were designed in total by groups of 2 or 3 pre-service teachers. Subsequent to the reviews made by taking into consideration the structure of the designed activities, the objectives in the mathematics curriculum, and the implementation conditions, two of the designed activities were implemented in the classroom.

\subsubsection{Views about Ethnomathematics Questionnaires}

During the design and implementation process of the ethnomathematics activities in the classrooms, the views of pre-service teachers, in-service teachers and students were gathered through questionnaires. During the research process, six questionnaires in total were administered at different times. These questionnaires are presented in Table 1. The questionnaires consisted of questions regarding issues, such as awareness of the relationship between mathematics and culture, prior learning, and designing and implementing activities in the teaching and learning process. During the questionnaire development process, the questions were reviewed by two researchers, one of whom held a $\mathrm{PhD}$ degree in mathematics education and the other had some expertise in conducting studies on culture and values in education. The questions were revised based on their expert opinions, and the questionnaires were ready to administer.

Table 1. Questionnaires on views about ethnomathematics, questions and purposes

\begin{tabular}{clc}
\hline Questionnaire & \multicolumn{1}{c}{ Questions } & Purpose \\
\hline & $\begin{array}{l}\text { At a breakfast gathering to which math teachers attend, one of the math } \\
\text { teachers assert that "Mathematics and culture are different fields that have } \\
\text { no common ground." Do you agree with this opinion? Please explain your } \\
\text { response. }\end{array}$ & Awareness \\
\hline & $\begin{array}{l}\text { Have you ever been in an ethnomathematics learning environment or in an } \\
\text { environment that can create knowledge / awareness about } \\
\text { ethnomathematics in your previous education life? / Have you established } \\
\text { an environment? Evaluate this situation in terms of qualification / reasons } \\
\text { / contributions etc. }\end{array}$ & Prior Learning \\
\hline & $\begin{array}{l}\text { Considering the activity, you designed, please explain the positive and } \\
\text { negative aspects (contribution-benefit, difficulty etc.) of the design } \\
\text { process in detail. Describe the situations that challenge you in the design } \\
\text { process. }\end{array}$ & $\begin{array}{c}\text { Activity Design } \\
\text { Process }\end{array}$ \\
\hline
\end{tabular}


Table 1 continued

\begin{tabular}{|c|c|c|}
\hline Questionnaire & Questions & Purpose \\
\hline $\mathrm{Q}_{4}$ & $\begin{array}{l}\text { Please explain the advantages and disadvantages of the implemented } \\
\text { activity. } \\
\text { Evaluate the efficiency of the implemented activity. (Scoring between 1- } \\
10 \text { and explanation (if any)) } \\
\text { - In terms of Teaching Mathematical Concept/Topic } \\
\text { - In terms of Cultural Transmission } \\
\text { - In terms of Students' Mathematics Learning } \\
\text { - In terms of Classroom Management } \\
\text { - In terms of Students' Interest in the Lesson } \\
\text { - In terms of Your Approach to the Activity }\end{array}$ & $\begin{array}{l}\text { Evaluation of } \\
\text { Activity } \\
\text { Implementation } \\
\text { Process }\end{array}$ \\
\hline $\mathrm{Q}_{5}$ & $\begin{array}{l}\text { Please provide information about the possible advantages and } \\
\text { disadvantages of ethnomathematics activities. When you start working as } \\
\text { a mathematics teacher / in your teaching life / in following lessons, do you } \\
\text { plan to use mathematics and culture related activities in your lessons? } \\
\text { Please explain your response in detail. }\end{array}$ & $\begin{array}{c}\text { Use in } \\
\text { Professional } \\
\text { Life }\end{array}$ \\
\hline $\mathrm{Q}_{6}$ & $\begin{array}{l}\text { Have you ever done an activity related to your culture in math classes? } \\
\text { Would you like to do activities related to your culture in following } \\
\text { mathematics lessons? } \\
\text { Between } 1 \text { and } 10, \text { what score would you give to this activity? } \\
\text { What did you learn from the activity? Please explain in detail. } \\
\text { Do you have any suggestions or comments about the activity? If yes, } \\
\text { please explain in detail. }\end{array}$ & $\begin{array}{l}\text { Evaluation of } \\
\text { Students }\end{array}$ \\
\hline
\end{tabular}

\subsubsection{Researchers' Field Notes}

Since the role of the researcher is of significant importance in qualitative methods, during the design process of ethnomathematics activities and the implementation process of the activities in the classroom environment, the researchers of the present study, in which the qualitative method was used, made observations, took notes of the salient situations, instant interviews and various evaluations. These notes contributed to the diversification of the findings and enabled an in-depth interpretation of the findings.

\subsubsection{Semi-Structured Interview Protocol}

Semi-structured interviews [SSI] were conducted with the pre-service teachers in order to elaborate on the data obtained from the questionnaires on views about ethnomathematics administered to pre-service teachers, and to explore the reasons behind written explanations. In order to increase data diversity, the views that preservice teachers had about the relationship between mathematics and culture (There is a relationship/No relationship) before the preparation phase, and the activities they designed/ implemented were considered while choosing the participants to be interviewed. In this context, 2 DPS and 2 IPS were selected for semi-structured interviews. Information about the interviewed pre-service teachers is presented in Table 2.

Table 2. Information about the interviewed pre-service teachers

\begin{tabular}{ccc}
\hline Participant & $\begin{array}{c}\text { The Relationship between Mathematics } \\
\text { and Culture }\end{array}$ & Designed/Implemented Activities \\
\hline $\mathrm{DPS}_{1}$ & No relationship & Cross-Stitching \\
\hline $\mathrm{DPS}_{2}$ & There is a relationship & DalliMat \\
\hline $\mathrm{IPS}_{1}$ & No relationship & MatCul \\
\hline $\mathrm{IPS}_{2}$ & There is a relationship & Cross-Stitching \\
\hline
\end{tabular}

The pre-service teachers were asked if they had any different views by presenting them or reminding them of their responses to the questions in the questionnaires on views about ethnomathematics and they were asked to elaborate on their views.

\subsection{Data collection process}

Data collection process of the research was carried out in three phases consisting of preparation, design and implementation as presented in Table 3. 
Table 3. Flow chart of data collection process

\begin{tabular}{|c|c|c|c|c|c|c|c|c|}
\hline Step 1 & Step 2 & Step 3 & Step 4 & Step 5 & Step 6 & Step 7 & Step 8 & Step 9 \\
\hline $\mathrm{Q}_{1}$ & \multirow{2}{*}{$\begin{array}{c}\text { Preparation } \\
\text { Phase }\end{array}$} & $\mathrm{Q}_{2}$ & \multirow{2}{*}{$\begin{array}{l}\text { Design } \\
\text { Phase }\end{array}$} & $\mathrm{Q}_{3}$ & \multirow{2}{*}{$\begin{array}{c}\text { Implementation } \\
\text { Phase }\end{array}$} & $\mathrm{Q}_{4}$ & $\mathrm{Q}_{6}$ & $\begin{array}{l}\mathrm{Q}_{1}-\mathrm{Q}_{5^{-}} \\
\mathrm{SSI}_{1}\end{array}$ \\
\hline $\begin{array}{c}\text { DPS, IPS, } \\
\text { T }\end{array}$ & & $\begin{array}{c}\text { DPS, IPS, } \\
\mathrm{T}\end{array}$ & & DPS & & $\begin{array}{c}\text { DPS, } \\
\mathrm{T}\end{array}$ & Student & $\begin{array}{c}\text { DPS, IPS, } \\
\mathrm{T}\end{array}$ \\
\hline
\end{tabular}

Before the preparation phase, Questionnaire 1 on Views about Ethnomathematics $\left[\mathrm{Q}_{1}\right]$ was administered to pre-service and in-service teachers in order to review their knowledge and views about the relationship between mathematics and culture. After the administration of $\mathrm{Q}_{1}$ in the context of the Culture and Mathematics course (see Table 4), the pre-service teachers were informed about the relationship between mathematics and culture, concepts related to cultural contexts, research studies conducted in the field of ethnomathematics and their basic principles, and the importance of incorporating ethnomathematics research studies into the classroom practice. Similarly, IPS and teachers were also informed about the relationship between mathematics and culture, and concepts related to cultural contexts. In addition, they were given a brief explanation about the research studies conducted in the field of ethnomathematics, and applications of ethnomathematics in the classroom practice were made by using the questioning method.

Table 4. The Culture and Mathematics course Definition of culture, the relationship between mathematics and culture

Mathematical concepts and cultural contexts (Ercan, 2005)

- Numbers, shapes, symbols, shapes drawn in the sand, logic of kinship relations

Definition of ethnomathematics and research studies conducted in the field of ethnomathematics

Use of ethnomathematics in the classroom practice

Ethnomathematics activities

- $\quad$ Yoruk Tents (Güreş, 2019), Seljuk Cupolas (Baki, 2014)

Design of ethnomathematics activities

After the preparation phase, Questionnaire 2 on Views about Ethnomathematics $\left[\mathrm{Q}_{2}\right]$ was administered to pre-service and in-service teachers to reveal their prior learning/experiences related to ethnomathematics, and then the design phase started. During the design process, DPS were asked to design in-class math activities related to the Turkish culture. In this process, the researchers held weekly meetings with the DPS, who were informed about the principles of activity design. DPS primarily searched for activities that could be designed related to the Turkish culture and had various ideas. Then, they associated the designed activities with the topics and objectives in the mathematics curriculum and anticipated possible problems that could arise during the implementation process of the activity and proposed solutions for the problems. The design phase was completed after approximately 5 weeks. A total of 9 different activities were designed. After the design phase, Questionnaire 3 on Views About Ethnomathematics $\left[\mathrm{Q}_{3}\right]$ was administered to the DPS for the evaluation of the design process.

After the administration of $\mathrm{Q}_{3}$, the activities that were designed were introduced in the activity presentation lesson, to which IPS also attended. The activities were given their final form by receiving the opinions of the pre-service teachers regarding the activities. It was decided that the activities named Cross-Stitching and MatCul would be implemented in the classrooms. It was determined that the MatCul activity (Appendix 1), related to square root of numbers, would be implemented in $8^{\text {th }}$ grade mathematics class, and Cross-Stitching activity (Appendix 2), related to geometric transformation, equality and equations and data analysis topics, would be implemented in $8^{\text {th }}$ grade mathematics applications. The implementation process started following the completion of this design process. Brief information about the implemented activities is provided in the appendices of the present article.

IPS prepared lesson plans for the activities to be implemented in the classrooms. The prepared lesson plans were examined in interviews conducted by the researchers and made ready for implementation. Two class hours were allocated for the Cross-Stitching activity and one class hour was allocated for the MatCul activity. During the implementation of the activities, the classes were observed by one of the researchers, a mathematics teacher and two pre-service teachers.

After the implementation, Questionnaire 4 on Views About Ethnomathematics $\left[\mathrm{Q}_{4}\right]$ was administered to the IPS and teachers with the aim of evaluating the activities and the implementation process, and the Questionnaire 6 on Views About Ethnomathematics $\left[\mathrm{Q}_{6}\right]$ was administered to the students in order to reveal the students' views about the lesson and the implemented activity. Subsequently, IPS and DPS held a meeting, during which IPS gave information about the implementation process to the DPS. Finally, Questionnaire 1 on Views About Ethnomathematics $\left[\mathrm{Q}_{1}\right]$ was administered in order to reveal the change in the knowledge and 
views of pre-service and in-service teachers about the relationship between mathematics and culture, and Views About Ethnomathematics Questionnaire $5\left[\mathrm{Q}_{5}\right]$ was administered in order to reveal the views of pre-service and in-service teachers about the use of ethnomathematics activities in professional life. Moreover, SSI was conducted with the pre-service teachers in order to enable them to elaborate on their views about designed and implemented activities.

\subsection{Data analysis}

The activities designed in the research process were analyzed in terms of curriculum (related topics, prior learning) and material use. The data obtained from the questionnaires were analyzed by creating codes and categories based on the characteristics of the questions in the questionnaires. To illustrate, for the data obtained from Q3, while categories such as contribution-benefit, difficulty and challenging situations were created for the process of designing ethnomathematics activities, for the data obtained from $\mathrm{Q}_{4}$, advantages and disadvantages categories were created for the process of implementing ethnomathematics activities. In addition, frequencies were calculated and codes related to categories were presented with the frequencies. Furthermore, some parts of the data obtained from the participants were transcribed, whereas some of them were presented directly.

\subsection{Trustworthiness of the study}

In qualitative research, the terms "credibility" is used for internal validity and "transferability" is used for external validity (Lincoln \& Guba, 1985). The expansion of the interaction between the researcher and the data over a wide period increases the credibility of the research data (Yıldırım \& Şimşek, 2013). In the present study, researchers and participants were in continuous interaction for an entire term. In qualitative research, generalization is not possible because the cases and facts are examined in depth and in detail, but the findings can be transferred merely to similar contexts or settings. Thus, in the present study, the research process has been described clearly and in detail. In addition, data triangulation and investigator triangulation were used in the study. For data triangulation, multiple sources of data, consisting of questionnaires, researchers' field notes and semi-structure interview protocol were used, and the findings from these data collection tools were compared and cross-checked. Moreover, for investigator triangulation, more than one researcher was involved in the data collection, data analysis and data interpretation processes. The participants' responses were analyzed by the researchers individually and then the researchers arrived at a consensus regarding the codes and categories during the long-lasting meetings.

\section{Findings}

The findings of the current study are presented in three sections. In the first section, the findings related to the designed activities, and the design and implementation process of these activities, and in the second section, the findings related to pre-service and in-service teachers' awareness of ethnomathematics, prior learning of ethnomathematics and use of ethnomathematics in professional life are presented. In the last section, the findings regarding the students' views about implemented activities are presented.

\subsection{Findings for the designed activities, and design and implementation process}

Nine activities were designed by the pre-service teachers during the research process. The designed activities were analyzed in terms of related topics, prior learning and material (see Table 5).

Table 5. Information about the designed activities

\begin{tabular}{lccc}
\hline Name of the Activity & Related Topics & Prior Learning & Material \\
\hline Cross-Stitching & Geometric Transformation & Equations/Statistics & A4 Drawing \\
\hline DallıMat & Geometric Transformation & Ratio/Proportion & $\begin{array}{c}\text { Cardboard Cutting- } \\
\text { Drawing }\end{array}$ \\
\hline Mosque & Perimeter-Area Calculation & Ratio/Proportion & Concrete Material \\
\hline Zeybek & Geometric Transformation & Coordinate System & Demonstration \\
\hline Historic Door & Geometric Transformation & - & $\begin{array}{c}\text { Construction Papers- } \\
\text { GeoGebra }\end{array}$ \\
\hline Mancala & Probability & - & Concrete Material \\
\hline Motifs & Geometric Transformation & Construction Papers \\
\hline MatCul & In this study, it is related to square root of numbers, but it \\
may also be related to different topics. & Game \\
\hline EthnoModelling & $\begin{array}{r}\text { In this study, it is related to topics in algebra learning area, } \\
\text { but it may also be related to different topics. }\end{array}$ & A4 Paper \\
\hline
\end{tabular}


Most of the designed activities were related to geometric transformation, but there were also activities related to topics, such as probability, geometric shapes and perimeter-area calculation. In addition, activities were also related to prior learning, such as equations, statistics, ratio/proportion and the coordinate system. Concrete materials, cardboard, and construction papers were generally used while designing activities. On the other hand, MatCul and EthnoModelling activities had the flexibility of being implemented in other topics. MatCul activity is a multi-stage game. The activity includes questions related to the Turkish culture and the square root of numbers. On the other hand, the EthnoModelling activity includes explanatory information about the Turkish culture and mathematical modelling questions related to this information.

Researchers' field notes included notes revealing that in the activity design process, DPS could not access academic resources, such as articles and theses either as hard copy or online in libraries, and that they generally used the search engine, Google Scholar, and various social media applications. In addition, it was included in the researchers' field notes that the fact that one of the pre-service teachers who designed the "Zeybek" activity knew how to perform zeybek folk dance and one of the pre-service teachers who designed the "Historic Door" activity had a special interest in the GeoGebra program may have influenced their choice of these activities.

The responses given to $\mathrm{Q}_{3}$ in order to evaluate the activity design process were analyzed in terms of positive views (contribution-benefit) and negative views (difficulties) (see Table 6).

Table 6. Contributions/benefits of and difficulties in the activity design process

\begin{tabular}{|c|c|c|}
\hline Category & Positive Views & f \\
\hline \multirow{7}{*}{$\begin{array}{l}\text { Contribution } \\
\text { Benefit }\end{array}$} & I have learned how to search about our culture and cultural elements. & 21 \\
\hline & I realized that mathematics and our culture are intertwined. & 20 \\
\hline & I learned how to convey a mathematics topic by associating it with a cultural element. & 15 \\
\hline & I gained knowledge of topics-objectives in the mathematics curriculum. & 21 \\
\hline & I gained experience in the activity design process. & 17 \\
\hline & I realized the importance of group work. & 8 \\
\hline & Negative Views & f \\
\hline \multirow{4}{*}{ Difficulties } & I experienced difficulty in deciding what kind of activity I could design. & 19 \\
\hline & $\begin{array}{l}\text { I experienced difficulty in associating the activity with the topic/objective in the } \\
\text { mathematics curriculum. }\end{array}$ & 11 \\
\hline & I experienced difficulty in planning the implementation of the activity in the classroom. & 21 \\
\hline & $\begin{array}{l}\text { I experienced difficulty in the use of tools and materials such as paper, cardboard, which } \\
\text { required fine motor skills in the activity design process. }\end{array}$ & 10 \\
\hline
\end{tabular}

DPS in the ethnomathematics activity design process indicated that they learned how to investigate culture and cultural elements $(\mathrm{n}=21)$ and gained awareness of the relationship between mathematics and culture $(\mathrm{n}=20)$. To illustrate, one DPS stated "Before I designed this activity, I could not establish a relationship between culture and mathematics and explain it in more than a few sentences...Thanks to this process, I had a chance to explore, recognize and notice the culture again." In addition, they specified that they learned topicsobjectives in the mathematics curriculum $(n=21)$, that they gained experience in the activity design process $(n=17)$ and learned how to convey mathematics by means of culture $(n=15)$. Some of the DPS $(n=8)$ also stated that group work was important in the activity design process. All of the DPS indicated that there was no negative effect and harm of the activity design process by stating, "I disagree with the idea that designing such an activity related to culture and mathematics may have a negative effect."

In the activity design process, DPS indicated that they had difficulties in deciding on the activity, associating the activity with the topic/objective, and planning the implementation of the activity in the classroom. One DPS said, "It was difficult to plan the implementation part while preparing the activity plan", while another said, "I had a difficulty in determining which objective would be achieved within the activity".

In the interviews, DPS $_{1}$ stated that the activity design process did not have a negative effect and use of cultural elements in mathematics lessons was a great advantage. $\mathrm{DPS}_{2}$ made similar explanations regarding the activity design process. She also stated that she gained experience in the activity design process, but she had a difficulty in cutting cardboards and making drawings.

$D P S_{2}$ : ... We made effort to design the activity because it was very difficult to cut paper and cardboard. Bindall was something we knew and always saw, but we actually discovered that could be used in mathematics. I'm very surprised about this situation...

In order to evaluate the activity implementation process, IPS' responses to $\mathrm{Q}_{4}$ were analyzed in terms of advantages (lesson, culture, mathematics) and disadvantages (classroom management) of the implemented activities and presented in Table 7. 
Table 7. Advantages and disadvantages of the implemented ethnomathematics activities

\begin{tabular}{|c|c|c|}
\hline Category & Advantages & $\mathbf{f}$ \\
\hline \multirow{5}{*}{ Lesson } & All students actively participated in the lesson. & 4 \\
\hline & Students' interest in the lesson increased. & 5 \\
\hline & Their motivation was higher compared to previous lessons. & 3 \\
\hline & $\begin{array}{l}\text { Students who did not ask for permission to speak in the previous lessons started to } \\
\text { speak. }\end{array}$ & 4 \\
\hline & More students wanted to speak/ go to the blackboard. & 5 \\
\hline \multirow{2}{*}{ Culture } & They obtained information about their culture. & 6 \\
\hline & They started to wonder about cultural elements. & 4 \\
\hline \multirow{4}{*}{ Mathematics } & $\begin{array}{l}\text { The number of students who could solve problems including square root of numbers } \\
\text { has increased. }\end{array}$ & 2 \\
\hline & $\begin{array}{l}\text { They gave different examples such as motif and ornament in the geometric } \\
\text { transformation topic. }\end{array}$ & 2 \\
\hline & They recalled the concepts they have had learned in previous years. & 3 \\
\hline & Disadvantages & $\mathbf{f}$ \\
\hline \multirow{3}{*}{$\begin{array}{l}\text { Classroom } \\
\text { Management }\end{array}$} & I experienced difficulty in classroom management. & 6 \\
\hline & I experienced difficulty in the drawings due to the traditional seating arrangement. & 3 \\
\hline & $\begin{array}{l}\text { During the implementation process there were situations (game rules-questions) that I } \\
\text { could not plan in advance. }\end{array}$ & 5 \\
\hline
\end{tabular}

IPS stated that ethnomathematics activities had positive effects on the lessons, such as increasing students' level of interest $(n=5)$ and motivation toward the lesson $(n=3)$. In addition, they stated that thanks to ethnomathematics activities students gained knowledge about their culture $(n=6)$, and they started to wonder about cultural elements $(n=4)$. Moreover, they indicated that ethnomathematics activities contributed to students' mathematics learning process $(n=7)$. On the other hand, IPS emphasized in their explanations that implemented activities caused disadvantages in classroom management $(n=6)$ and problems in the implementation process $(n=5)$.

When the responses given by the in-service teachers to $\mathrm{Q}_{4}$ during the implementation process were examined, it was seen that the most important advantage of the activities was the effect on the students' attitude towards mathematics. In addition, teachers stated that it was important to inform students about culture, to associate culture with mathematics and to equip students with a different perspective. However, according to $\mathrm{T}_{2}$ and $\mathrm{T}_{1}$, the intensiveness of the curriculum and crowded classrooms, respectively, would create disadvantages in implementing the activity (see Figure 1).

\section{Msfredatton kgnakl, Oleak et kinlik sok soron alabilir.}

(In English: The activity may take a lot of time due to the curriculum)

Ancok sinif lor kalabalik. Bu durumda yapacajm etkinlik her g̈prencim icin esit sekilde

(In English: However, the classrooms are crowded. In this case, the activity I will implement is not equally beneficial for each student.)

Figure 1. In-service teachers' views about the disadvantages of ethnomathematics activities

It was included in the researchers' field notes that the implementation process of the activities was both entertaining and instructive, and the students' interest and participation in the lesson was high (see Figure 2).

\section{2. dokika: Siny icerisinde 9 ygurenci poriok koldirip soz lakki isterkte

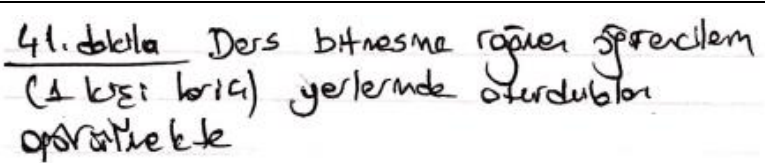

(In English: 22 ${ }^{\text {nd }}$ minute: In the classroom, 9+4 students raised their hands and asked for permission to speak)

(In English: $41^{\text {st }}$ minute: Although the class had ended, it was observed that the students (except 1) were sitting at their desks).

Figure 2. Examples from researchers' field notes 


\subsection{Findings for the awareness of ethnomathematics, prior learning of ethnomathematics, and use of ethnomathematics in professional life}

In order to reveal the level of pre-service and in-service teachers' awareness of the relationship between mathematics and culture, $\mathrm{Q}_{1}$ was administered both before and after the preparation phase. Before the preparation phase, 6 DPS, 2 IPS and $\mathrm{T}_{2}$ stated that mathematics and culture are related to each other. After the implementation phase, a remarkable finding emerged and all pre-service and in-service teachers stated that mathematics and culture were related (see Table 9).

Table 9. Analysis of explanations regarding the relationship between mathematics and culture

\begin{tabular}{|c|c|c|c|c|}
\hline Relationship & Before Preparation Phase & DPS & IPS & Teachers \\
\hline \multirow{2}{*}{$\begin{array}{l}\text { There is a } \\
\text { relationship }\end{array}$} & History of mathematics and presence of scientists & 6 & 2 & 0 \\
\hline & $\begin{array}{l}\text { There is mathematics in old structures and carpet } \\
\text { motifs. }\end{array}$ & 0 & 0 & 1 \\
\hline \multirow{2}{*}{$\begin{array}{l}\text { There is no } \\
\text { relationship }\end{array}$} & $\begin{array}{l}\text { Mathematics consists of rules and formulas. Culture } \\
\text { affects social life. }\end{array}$ & 12 & 4 & 1 \\
\hline & $\begin{array}{l}\text { Mathematics is related to formulas and culture is } \\
\text { related to traditions and customs. }\end{array}$ & 4 & 0 & 0 \\
\hline Relationship & After Implementation Phase & DPS & IPS & Teachers \\
\hline \multirow{5}{*}{$\begin{array}{l}\text { There is a } \\
\text { relationship }\end{array}$} & $\begin{array}{l}(\mathbf{M} \rightarrow \mathbf{C}) \\
\text { Mathematics was used in the formation of many } \\
\text { elements in our culture. } \\
\text { Mathematics is a means of cultural transmission. }\end{array}$ & 7 & 3 & 0 \\
\hline & $\begin{array}{l}(\mathbf{C} \rightarrow \mathbf{M}) \\
\text { Culture has an important place in the emergence of } \\
\text { mathematical concepts. } \\
\text { The development of mathematics has been influenced } \\
\text { by culture. }\end{array}$ & 10 & 2 & 0 \\
\hline & $(\mathrm{M} \leftarrow \rightarrow \mathrm{C})$ & & & \\
\hline & $\begin{array}{l}\text { There is a bidirectional relationship between } \\
\text { mathematics and culture. }\end{array}$ & 3 & 1 & 2 \\
\hline & Mathematics is in every part of daily life. & 2 & 0 & 0 \\
\hline
\end{tabular}

Prior to the preparation phase, the vast majority of pre-service teachers $(n=20)$ and $T_{1}$ stated that mathematics consisted of precise and unchangeable facts with rules and formulas, and that culture was related to the history of individuals and societies, and therefore, they stated that mathematics and culture were not related. The remaining pre-service teachers $(n=8)$ and $T_{2}$ emphasized the history of mathematics and indicated that mathematics and culture were related by stating that there was mathematics in the houses built in ancient times and in carpet motifs.

Subsequent to the implementation, the pre-service and in-service teachers explained the relationship between mathematics and culture in four ways. While the first three include the idea that mathematics and culture affect each other in a unidirectional or bidirectional manner (mathematics affects culture [M $\rightarrow C]$, culture affects mathematics $[\mathrm{C} \rightarrow \mathrm{M}]$ and mathematics and culture bidirectionally affect each other $[\mathrm{M} \leftarrow \rightarrow \mathrm{C}]$ ), the last type explanation focuses on the idea that mathematics is in every part of daily life. In the $M \rightarrow C$ relationship, mathematics is a tool in the formation and transmission of culture. In $\mathrm{C} \rightarrow \mathrm{M}$ relationship, culture affects the emergence of mathematical concepts and the development of mathematics. The relationship $\mathrm{M} \leftarrow \rightarrow \mathrm{C}$ refers to a dynamic process in which culture and mathematics bidirectionally affect each other.

After the preparation phase, $\mathrm{Q}_{2}$ was administered to pre-service and in-service teachers in order to identify their prior learning of ethnomathematics. Five of the pre-service teachers stated that they had been in a learning environment related to ethnomathematics in their previous education life. These pre-service teachers mentioned the History of Mathematics course $(n=2)$ they taken during the first semester, the museum tour they had attended in middle school $(\mathrm{n}=2)$ and the Istanbul Miniatürk trip as examples. In both the questionnaire and interviews, the pre-service teachers stated that these experiences were not sufficient for them. On the other hand, in-service teachers stated that they did not intend to create an ethnomathematics environment in their lessons, but they sometimes provided information about the history of the mathematical concepts and topics.

$I P S_{2}:$... I have been to the museum once before, but there could be a common point between mathematics and culture in a very different way.

Interviewer: So, is your museum visit during high school enough to see the relationship between culture and mathematics? 
$I P S_{2}$ : It is never enough. There is a very different relationship between mathematics and culture. We just did a little bit about this relationship.

The pre-service teachers who did not encounter ethnomathematics in their prior learning mentioned teachercentred education, the limited teaching duration of concepts in the curriculum, and in-service teachers' lack of knowledge about ethnomathematics as reasons for not having been in learning environments related to ethnomathematics. They stated the possible consequences of this situation as one-sided perspective on mathematics and not learning the emergence of mathematics and its relationship with the culture. For instance, IPS $_{1}$ stated that before implementation she considered that mathematics and culture were very different fields, whereas DPS ${ }_{1}$ stated that mathematics was a culture-free field in which problems were solved by rules and methods. Furthermore, DPS $_{1}$ stated that teachers lacked knowledge in this area, and added that she would not feel incompetent thanks to the course she had taken.

IPS $S_{1}$.... Actually, it is interesting to me that I have never learned such activities until now. I thought that mathematics and culture were quite different at the beginning of the term. In fact, I laugh at myself as I remember this thought. Maybe since I have not learned it, I want to practice more...

$D P S_{1}:$... It is very interesting that cultural things that seem unrelated to mathematics can be used in mathematics lessons. More precisely, when I was a student, I never saw mathematics like this. I always solved multiple choice problems with rules and methods. However, it would be great to learn mathematics like this by using Kanaviçe, Bindall, Mosque, Zeybek. I feel incompetent about this...

$D P S_{1}:$... I think that my teachers do not know much about these issues. Because if I had not taken such a lesson, maybe I would not know about it. If I hadn't designed this activity, I wouldn't have thought that I could use it.

All pre-service and in-service teachers stated that they would use ethnomathematics activities in their professional lives and supported this with the explanations presented in Table 10.

Table 10. Views about the use of ethnomathematics activities in professional life

\begin{tabular}{|c|c|c|c|c|}
\hline Category & Code Examples & DPS & IPS & Teachers \\
\hline $\begin{array}{l}\text { Perspective } \\
\text { toward } \\
\text { Mathematics }\end{array}$ & $\begin{array}{l}\text { The perspective toward mathematics changes. } \\
\text { Application areas of mathematics, other than formulas and } \\
\text { rules, are seen. } \\
\text { Prejudices can be destroyed. }\end{array}$ & 12 & 5 & 2 \\
\hline Lesson & $\begin{array}{l}\text { Interest in the lesson increases. } \\
\text { They increase motivation. } \\
\text { They make the lesson enjoyable. }\end{array}$ & 21 & 6 & 1 \\
\hline $\begin{array}{l}\text { Mathematics } \\
\text { and Culture }\end{array}$ & $\begin{array}{l}\text { The relationship between mathematics and culture is learned. } \\
\text { Students can learn our culture. } \\
\text { They form an awareness about cultural elements. }\end{array}$ & 14 & 5 & 2 \\
\hline
\end{tabular}

The pre-service teachers explained the reasons for using ethnomathematics activities in their professional lives by mentioning the change in the students' perspectives on mathematics $(n=17)$, the recognition of the relationship between mathematics and culture $(n=19)$ and its positive effects on the lesson $(n=27)$ (see Figure 4). Similarly, in-service teachers made similar explanations regarding the positive aspects of the use of ethnomathematics activities in professional life.

Interviewer: ... So, would you think of using these kinds of activities in your professional life? $D P S_{1}$ : I absolutely think so. I will use all of the activities we designed in the course.

$\mathrm{DPS}_{2}$ : Of course, I think so because we can start learning without fear of learning mathematics in our own activity. Since students fear mathematics, I think that it is very necessary.

$I_{P S}$ : I am thinking of implementing them. We have designed many activities. I backed them up on my computer. I will continue to search if there are any other activities.

$T_{2}$ : I realized that I can implement them. Students' interest in the lesson and motivation may increase to the desired level. It is also beneficial for students to learn culture and to see its relationship with mathematics.

$T_{1}$ : I will use them in my lessons. It will be an opportunity for my students to see an aspect of mathematics that does not include an operation and a formula. 


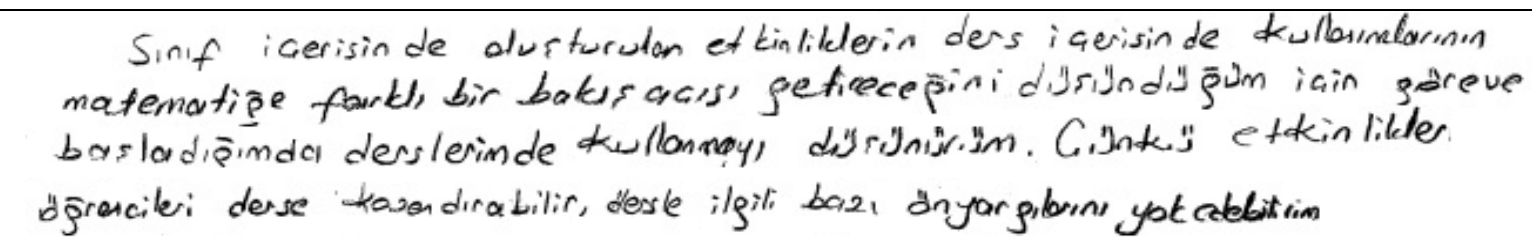

(In English: Since I think that the use of activities created in the classroom will bring a different perspective to mathematics, I will consider using them in my classes when I start working because the activities can help the students participate in the lesson and eliminate some of their prejudices about the lesson.)

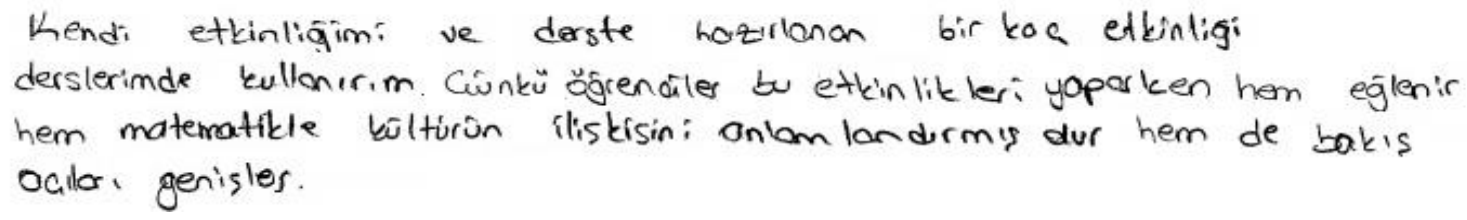

(In English: I will use my own activity and a few activities designed in this course in my lessons because while students are doing these activities, they have fun, they make sense of the relationship between mathematics and culture, and their perspectives expand.)

Figure 4. Views of pre-service teachers about the use of ethnomathematics activities in their professional lives

\subsection{Findings of the students' views about the implemented activities}

All of the students $(n=71)$ in the classes where the ethnomathematics activities were implemented stated that they did not do any cultural activities in the previous mathematics lessons. 62 of the students indicated that they wanted to do similar activities related to culture in the following mathematics lessons, whereas 9 of them did not want these activities to be implemented. The students who wanted to do these kinds of activities emphasized that the activities were enjoyable and that they gained knowledge of mathematics and culture by means of these activities (see a,b in Figure 5). The students who did not want the activities to be implemented in the classes stated that there was a noise problem in the classroom and that mathematics was not covered in the lesson (see c in Figure 5).

$\mathbf{a}$

$$
\begin{aligned}
& \text { matematile dersininde eglenceli olabilecesin }
\end{aligned}
$$

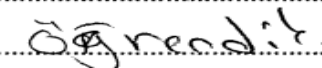

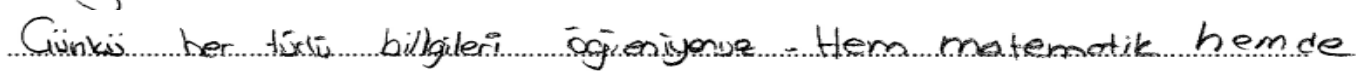

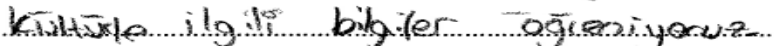

c

(In English: a) We realized that mathematics lessons could also be enjoyable.

b) Because we learn all kinds of knowledge. We learn knowledge related to both mathematics and culture.

c) In the mathematics lesson, mathematics should be taught)

Figure 5. Students' views about the implemented activities

It was observed that 9.14 was the average score of the students' responses to the question, "Between 1 and 10, what score would you give to this activity?" which was asked with the aim of evaluating the implementation process from the students' perspective. In addition, the responses given by the students to the question "What did you learn from the activity?" are presented in Table 11.

Table 11. Students' views on learning with the aid of the activities

\begin{tabular}{llc}
\hline Category & Code Examples & f \\
\hline \multirow{2}{*}{ Culture } & I learned about our culture. & 59 \\
\cline { 2 - 3 } & I learned how to embroider on canvas. & 21 \\
\hline \multirow{3}{*}{ Mathematics } & I learned how to solve problems including square root of numbers. & 19 \\
\cline { 2 - 3 } & I learned geometric transformation. & 21 \\
\cline { 2 - 3 } & I recalled the topic of equations. & 11 \\
\cline { 2 - 3 } & I recalled how to draw graphs. & 7 \\
\hline
\end{tabular}

With the help of the activities, students stated that they learned about their culture $(n=59)$ and canvas $(n=21)$, as well as mathematical concepts and topics such as square root of numbers $(n=19)$, geometric transformation $(\mathrm{n}=21)$, equations $(\mathrm{n}=11)$, and drawing graphs $(\mathrm{n}=7)$. 
To the question "Do you have any suggestions or comments about the activity?", students generally gave positive responses $(n=29)$ and stated that they wanted to do such activities at different times (Figure 6a-6b). In addition, some students $(n=7)$ stated that the number and variety of questions in the activity should increase because more challenging questions were asked in the exams (Figure 6c). Four students stated that the activities were unnecessary and should not be used in mathematics lessons (Figure 6d). It was observed that these students were those who did not want to do activities in mathematics lessons. On the other hand, the remaining 21 students did not make any suggestions and comments.

$\mathbf{a}$

6. Etkinlik ile ilişkili önerileriniz ya da görüşleriniz var mıdır? Var ise lütfen detaylıca açıklayınız.

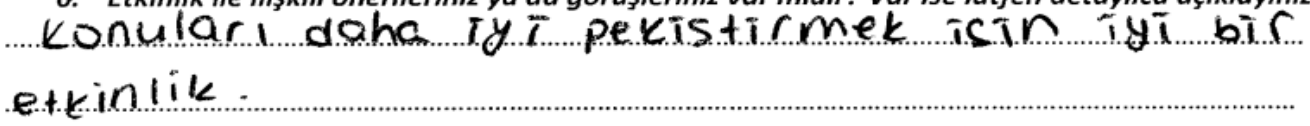

b

6. Etkinlik ile ilişkili önerileriniz ya da görüşleriniz var mıdır? Var ise lütfen detaylıca açıklayınız.

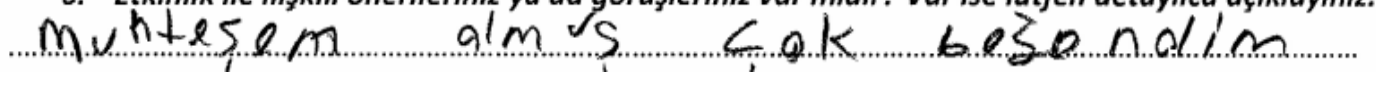

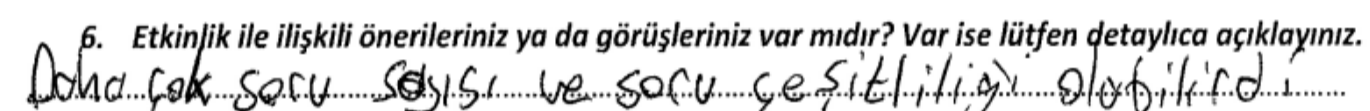

c

6. Etkinlik ile ilişkili önerileriniz ya da görüşleriniz var mıdır? Var ise lütfen detaylıca açıklayınız.

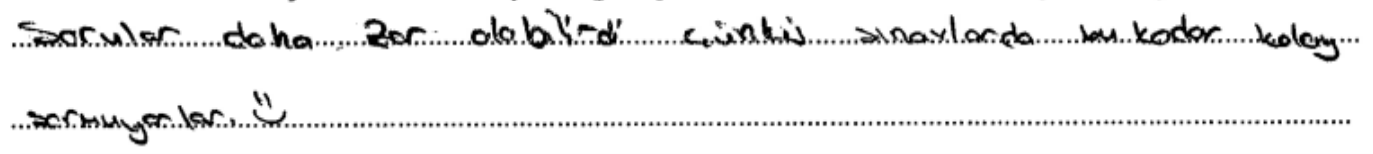

d

6. Etkinlik ile ilişkili önerileriniz ya da görüşleriniz var mıdır? Var ise lütfen detaylıca açıklayınız.

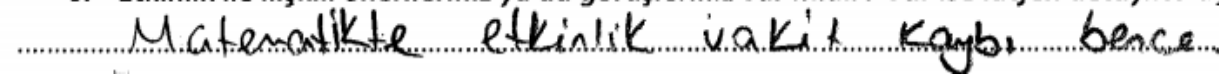

(In English: a It is a good activity to reinforce the concepts further.

b It is wonderful. I liked it so much.

c There could have been a higher number and variety of questions.

d I think that activities in mathematics is a waste of time)

Figure 6. Students' suggestions and comments about implemented activities

\section{Discussion and Conclusion}

The present study aimed to examine the ethnomathematics activities designed by pre-service mathematics teachers in terms of the pre-service teacher variable, the implementation of the designed activities in the classroom environment in terms of the pre-service, the in-service teachers and student variables and to determine pre-service and in-service teachers' awareness of ethnomathematics, their prior learning of ethnomathematics and their use of ethnomathematics in professional life. In line with this purpose, nine activities were designed by the pre-service teachers and two of these activities were implemented in the classroom. It is necessary for pre-service teachers to practice in school settings and gain experience in addition to having theoretical knowledge (Ayas, 2009). When this necessity is considered, it is important to consider the reflections of theoretically designed activities on the implementation process in terms of addressing both theory and practice.

It was observed that the designed activities were generally related to the geometry learning domain. This may have stemmed from the frequent occurrence of geometrical concepts in cultural elements (Snipes \& Moses, 2001) and geometric shapes in carpet motifs, figures, mosque ornaments and local clothes in the Turkish culture. Pre-service teachers often encountered these cultural elements in the searches that they made by using web-based tools or various social media applications. Furthermore, the selection of the Mancala activity, which is one of the activities outside the geometry learning domain, could be related to the searches made by the pre-service teachers since the Mancala game appears at the top in web-based searches (Zaslavsky, 1998). Associating the designed activities with prior learnings can be seen as a strong aspect of the activities since the mathematics curriculum follows a spiral structure. Lack of activities on different topics can be a result of the limited resources in the field of ethnomathematics and insufficiency of existing resources. Limited research and the insufficient number of books in the field of ethnomathematics have caused pre-service teachers to experience difficulties in deciding on the activity in the design process. Moreover, since the preservice teachers who have designed activities were in their 3rd semester at the time of the study, they do not have comprehensive pedagogical content knowledge nor curriculum knowledge. This situation may have also caused difficulties in the process of designing activities. In addition, individual characteristics of pre-service teachers, such as playing the zeybek folk dance at a professional level or using the GeoGebra program well, were also determinants in the decision-making process. 
The process of designing an activity enabled pre-service teachers to gain experience, improved their knowledge of cultural elements, raised their awareness of the relationship between culture and mathematics, and cultivated in pre-service teachers the ability to use a cultural element in mathematics lessons and knowledge of mathematics curriculum. This may indicate that the process of designing activities provides positive contributions to pre-service teachers' general, pedagogical and pedagogical content knowledge. Designing activities related to ethnomathematics can contribute to pre-service teachers' professional development. Moreover, pre-service teachers emphasized that group work is important in this process. Working within groups, exchanging ideas within the group, respecting the ideas of the members of the group, the ability to defend one's own ideas are important in the ethnomathematics approach and support the idea of emphasizing group work (Kelly, 2005). In addition, preservice teachers stated that there was no negative effect and disadvantage of the process of designing activities. This could be an indicator of selecting study group that is appropriate to the purpose of the research.

The activity named "Cross-Stitching" was used in the process of teaching the concept, and the activity named "MatCul" was used in the process of assessing students' learning. One of the most remarkable reflections from the implementation process of the activities was the increase in students' participation and interest in the lesson. Pre-service teachers who had made observations and taught in these classes before (within the context of Teaching Practice I course) stated that there were significant differences in the lessons where ethnomathematics activities were used when compared to previous lessons. This situation indicates that the use of ethnomathematics activities in the classroom is important and useful (Spines \& Moses, 2001). Teachers also stated that the activities increased students' interest in the lesson and helped students develop a positive attitude towards mathematics. The high average of the scores that students gave to the activities and their positive views about the activities support this situation. With these findings, it can be said that the implementation of ethnomathematics activities creates a positive attitude toward mathematics in students (Aktuna, 2013; Kara, 2009). In addition, the activities received the maximum score from both pre-service and in-service teachers in terms of cultural transmission. Students have gained knowledge about their culture and have begun to wonder about the cultural elements by means of the ethnomathematics activities. These are positive reflections, which were specified as advantages by the pre-service and in-service teachers in the lessons.

It was emphasized by the pre-service and in-service teachers that the activities were effective in teaching and learning mathematical concepts. This also supports the notion that ethnomathematics is a field that increases achievement (Magallanes, 2003) and improves mathematical understanding (Widada et al., 2018) and mathematical thinking skills (Iluno \& Taylor, 2013; Powell \& Temple, 2001). The fact that the pre-service teachers made higher-scored evaluations in terms of mathematics teaching and learning compared to in-service teachers can be explained by their perspectives toward ethnomathematics. In addition, the fact that pre-service teachers made higher-scored evaluations than in-service teachers regarding their approach to activities supports this situation. If we look from the viewpoint of in-service teachers, this situation can be evaluated differently when aspects such as knowledge of holistic curriculum and appropriateness of the concepts to teach, target behaviours to be gained, expectations, and the examination system were taken into account. The negative views of some students regarding the ethnomathematics activities could be related to the individual characteristics of the students, such as their learning methods, desires, and mathematical beliefs because the students who stated that it is not necessary to use the ethnomathematics activities in the lessons also opposed the use of math activities in the lessons.

The biggest problem in the implementation process of ethnomathematics activities is the classroom management problem. Although this situation is expected in an activity implementation process (Şahin \& Eraslan, 2019), it can be also due to the pre-service teachers' lack of experience. While evaluating the lessons in terms of classroom management, it was observed that the more experienced in-service teacher gave higher scores than the less experienced one and both of the in-service teachers gave higher scores than the pre-service teachers. This can be an indicator of the fact that experience leads to improvement in classroom management skills. It can be claimed that classroom management is a skill that can be acquired over time and classroom management problem should not be seen as a disadvantage for implementing ethnomathematics activities in the class. Thus, it was revealed that ethnomathematics activities have a positive effect on cultural transmission, mathematics teaching and attitude towards mathematics in accordance with the purpose of the research. Students' views and field notes of the researchers also support these findings.

Students' explanations that similar activities related to culture and mathematics were not included in their previous lessons, in-service teachers' explanations that they did not use ethnomathematics in the lessons, and pre-service teachers' thoughts were consistent. This situation indicates that ethnomathematics is almost never used in mathematics lessons, and this finding is consistent with the related literature (D'Ambrosio \& Rosa, 2017; Kang, 1992). When the importance of ethnomathematics is considered, extending the duration of ethnomathematics based course processes in mathematics lessons (as in this study) should be regarded as a 
necessity (Shirley, 2001; Presmeg, 1998). Although this requirement was put forward by MoNE (2018) and HEC (2018), there are deficiencies in the curriculum in terms of the objectives to be achieved. One of the biggest obstacles of this situation is that in-service teachers are not ready for ethnomathematics (Lewis, 2016); hence, educating pre-service teachers in this sense has been a strong point for consideration in this research. The fact that students wanted similar activities to be done in the subsequent lessons and put forward the suggestion of increasing the number and variety of questions in the activities is an important finding for the use of similar activities in subsequent math lessons. With the increase in the use of ethnomathematics activities in the classroom, students can realize that there is an interaction between the culture and mathematics lessons (Bishop, 1994; Zaslavsky, 1998). This may also eliminate the lack of education in the area of ethnomathematics, highlighted by d'Entremont, (2015) and Krummel (2013). In this way, curricula can be developed in terms of cultural perspectives (Mukhopadhyay \& Greer, 2013; Rosa \& Orey, 2011).

One of the important findings of the present study is that there was an increase in the ethnomathematics awareness of pre-service and in-service teachers. Before the study, they mentioned that there was no relationship between culture and mathematics or there was a relationship only at the basic level. This situation may stem from the fact that academic mathematics is taught in classroom settings and the curriculum is not associated with cultural elements (D'Ambrosio, 2001). At the end of the study, pre-service and in-service teachers stated that there was a unidirectional or bidirectional relationship between mathematics and culture: $\mathrm{M} \rightarrow \mathrm{C}, \mathrm{C} \rightarrow \mathrm{M}$ and $\mathrm{M} \leftarrow \rightarrow \mathrm{C}$. This showed that the design and implementation of ethnomathematics activities in the classroom environment raised the awareness of pre-service and in-service teachers about the relationship between culture and mathematics. Pre-service and in-service teachers learnt that their culture was related to mathematics by experiential practice. This situation reveals that the aim of valuing culture, which is one of the important goals of ethnomathematics (D’Ambrosio \& Rosa, 2017), which has been achieved. Thus, it has been concluded that the relationship between mathematics and culture can be transferred easily through research that may conducted and by means of learning environments that may be organized.

In the research process, it was observed that pre-service and in-service teachers' perspectives have changed. In addition, their level of awareness of the relationship between mathematics and culture has increased. Preservice teachers realized that mathematics has an application-oriented aspect other than formulas and rules and it is frequently included in their culture. This will provide an understanding of the nature of mathematics (Barta, 2001) and new answers to questions, such as "What is mathematics used for?" and "What is the role of mathematics in our life?", which are considered clichés but are not answered in depth. In addition, when mathematics curricula involving cultural elements are implemented, it was observed that these cultural elements had significant effects on students, deepened students' understanding of mathematics, and helped students see mathematics as a part of their daily lives as well as develop meaning ful connections (Bishop, 1994; Stathopoulou, 2017; Zaslavsky, 2002). It can be said that when curriculum and lesson plans are designed with ethnomathematics in accordance with the cultural environment of the students, this will indicate that mathematics is used in daily life.

\section{Suggestions}

Pre-service teachers' incomplete or inaccurate knowledge about mathematics and culture as interrelated fields at the beginning of the research is thought-provoking in terms of mathematics education because the relationship between culture and mathematics explains the nature of ethnomathematics (D'Ambrosio, 2001). When the importance of ethnomathematics is considered, conducting research similar to the present study gains importance at this point. Furthermore, although ethnomathematics is emphasized in the curriculum, it was revealed in the research process that mathematics is taught in the classroom as independent of ethnomathematics. In order to overcome this situation, pre-service and in-service teachers' awareness of ethnomathematics should be increased. Although pre-service and in-service teachers are willing to use cultural elements in mathematics lessons, there is lack of materials and guidebook on how to achieve this. In this context, while developing the mathematics curriculum, it is suggested that studies including activities that enable students to establish the relationship between mathematical concepts and culture, as well as activities that can be used in the lessons by the teachers similar to the activities designed in this research, should be included. In addition, detailed evaluations can be made by designing learning environments involving activities similar to those designed in this research and by conducting interviews with in-service teachers and students. Finally, learning environments can be associated with variables such as achievement, motivation, attitude, and anxiety.

Ethics Committee Approval Information: Ethics committee approval for this research was obtained from Sakarya University, Social and Humanities Ethics Committee, with the date of 03.18.2020, document number E.3607, and resolution 21 (see for the details). 
Name of the Activity: MatCul

\section{Appendix 1}

Learning Area: Numbers and Operations

Sub-Learning Area: Square Roots of Numbers

Purpose of the Activity:

- To solve the problems related to the objectives about square roots of numbers that take place in the Middle Grades Mathematics Curriculum,

- To inform about the elements in our culture

- Introducing important scientists in the history of mathematics

Duration: $40 \mathrm{~min}$.

Grade Level: 8

Number of Students: 24

Implementation Method: Group Work (Groups of 8 students)

Implementation Process: Groups of eight students and group leaders sit at the round table. Two teams of four students are formed in each group. The groups are asked to roll the dice...Brief information about the scientist opposite the number directed by the yellow arrow is provided by the group leader. If the number that comes after the information is positive, the game starts. After the game starts, a brief information letter about the culture written below each step is read. The answer of the group is requested at the end of the period determined with the sandglass. Each correct answer to cultural elements will give the right to repeat rolling if a negative number is received, and five correct answers in total will give you a right to progress one step... After the answer to the culture question is received, the group members are asked to choose a random mathematics question among the questions related to the color in the arrow direction and then they are asked to solve mathematical problem.

\section{Examples for Mathematics Problems}

- How many natural numbers can be substituted for $\mathrm{x}$ to make $\sqrt{5-x}$ irrational?

- Calculate the length of the perimeter of the rectangle with one side $\sqrt{180} \mathrm{~cm}$ and the other side $\sqrt{128} \mathrm{~cm}$.

- How many of the natural numbers between $\sqrt{29}$ and $\sqrt{101}$ are even?

\section{Examples for Questions related to Culture}

- It is a game that is reflected on the screen for entertainment, usually after iftar in Ramadan. There are two leading roles in the game.

- It is a type of knitting created with white cotton thread and by using tools such as crochet hooks, generally by making chain stitch or tying various knots with needle.

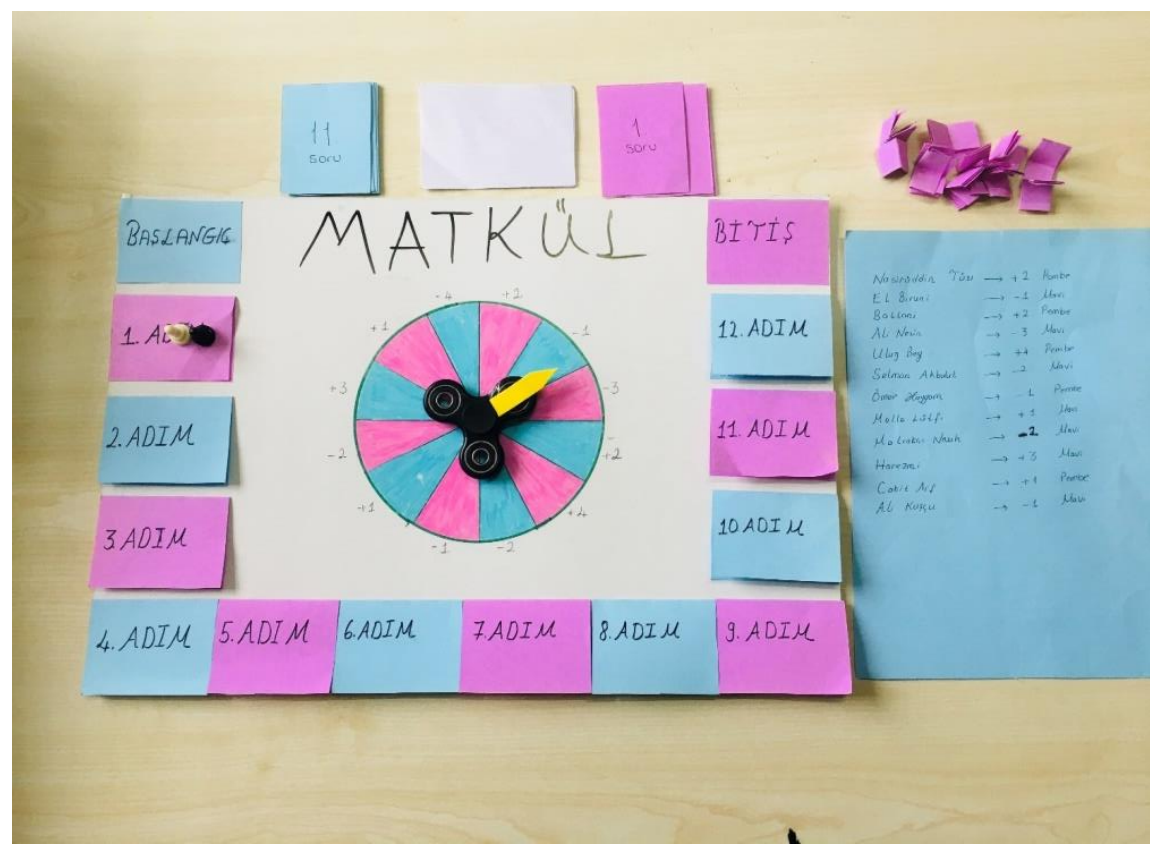

You can contact the corresponding author for further information regarding the activity.- 
Name of the Activity: Cross-Stitching

\section{Appendix 2}

\section{Learning Area: Geometry \\ Sub-Learning Area: Geometric Transformation \\ Purpose of the Activity:}

- Achieving the objective "MU.8.3.2.1. Determines the application areas of geometric transformation." that takes place in the Middle Grades Mathematics Curriculum,

- Introducing cross stitch that exists in our culture, and demonstration of how to make cross stitch.

Duration: $80 \mathrm{~min}$.

Grade Level: 8

Number of Students: 28

Implementation Method: Individual/Group Work ( 2 or 3 students)

Implementation Process: Cross stitch samples are examined by all students. Then, students are asked what is cross stitch? Do you know anything about cross stitch? Have you ever seen cross stitch before? Do you have cross stitch in your home? Do you know any of your elders who make cross stitch? How cross stitch is made? After that, the A3-sized drawings that are brought to the classroom are distributed to students and students examine them. Students are asked to interpret the features of the drawings they notice, and their comments are written on the board by the secretary student. Students begin to create these cross stitch drawings gradually from simple to complex. At the first phase, students are asked to examine the completed cross stitch below. In the second phase, students are asked to complete half of the cross stitch by finding its symmetry with respect to the y-axis. In the third phase, students are asked to complete the cross stitch drawing whose one part has been given by translating. In the fourth phase, students work on blank squared A3 paper and draw the desired cross stitch with the method they want.

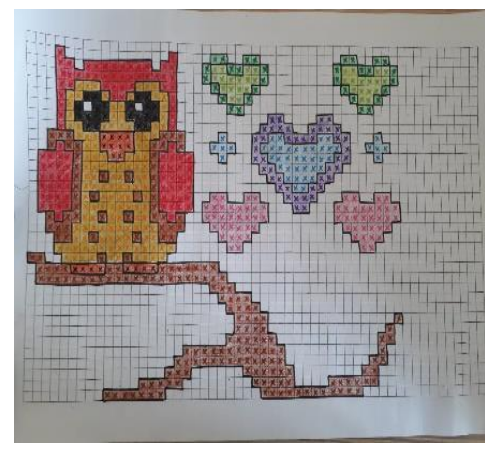

Phase 1

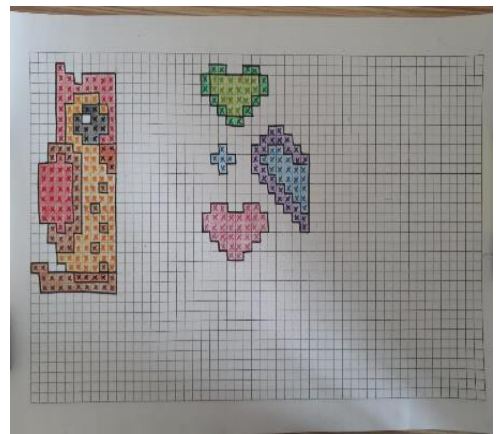

Phase 2

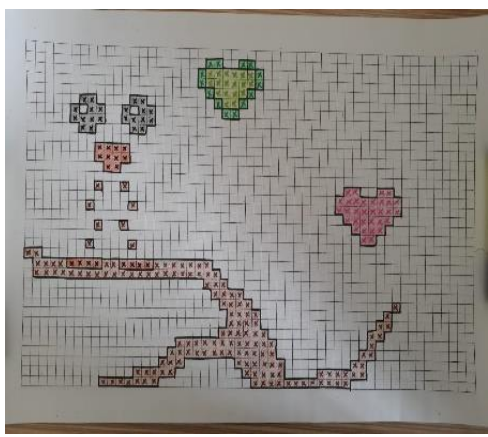

Phase 3

At the end of the activity, evaluation problems are presented to the students and problems are solved by students.

\section{Examples for Evaluation Problems}

- If Uncle Esref uses $4 \mathrm{~cm}$ thread for 3 loops in owl cross stitch, what is the amount of thread required to obtain the cross stitch we want to make? (In this question, the amount of thread required for the cross stitch whose different parts are left missing is meant. Owl cross stitch $=672$ loops)

- Sort the amount of thread used according to their colours and find the range of the data.

- If there is a proportional relationship between the amount of threads used to complete the cross stitch according to the colours, please write them.

Cross stitch (below) is given to students as a homework.

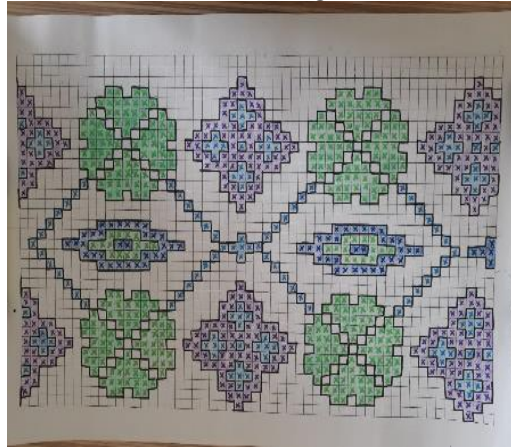

Phase 1

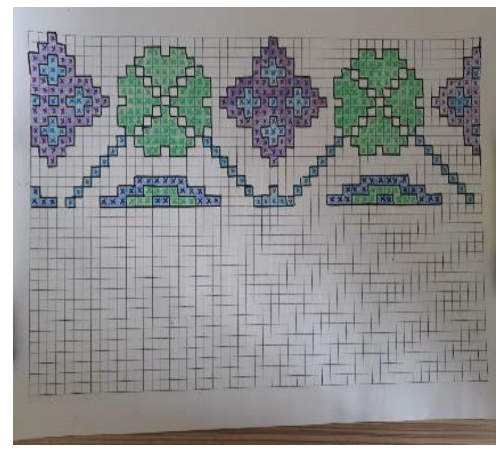

Phase 2

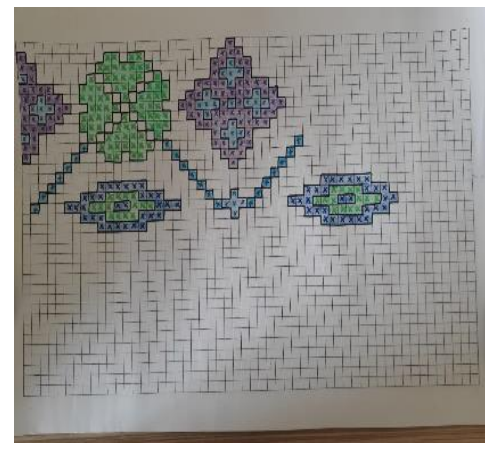

Phase 3

You can contact the corresponding author for further information regarding the activity. 


\section{Etnomatematik Etkinlikler: Tasarlama ve Uygulama Sürecinden Yansımalar}

\section{Giriş}

"Matematik ortaya nasıl çıkmıștır?" sorusu günümüzde halen tartışılmakta ve bu soru üzerine uzlaşılmış bir cevap bulunmamaktadır. Bununla birlikte matematik tarihi incelendiğinde felsefe ile matematiğin iç içe olduğu görülmektedir (Baki, 2014). Ayrıca matematik çoğu zaman soyut olarak görülmekte, sadece formül ve teoremlere dayalı hesaplamalar ile ilişkilendirilmektedir. Bu düşünce matematiğin ortaya çıkışındaki felsefe, kültür ve değer gibi etkileri de görmezden gelmektedir. Oysaki matematik cam bir fanusun içerisinde bireyden ve kültürden bağımsız olarak gelişmemiş̧tir. Matematik, ortaya çıkışında ve gelişiminde kültür ve değerlerin önemli bir yere sahip olduğu bir düşünce sistemidir (Leitze, 1997; Lim ve Ernest, 1997; Zaslavsky, 1998). Bu bağlamda kültür ve matematiğin ilişkisini konu edinen etnomatematik adı altında bir araştırma alanı doğmuştur. Matematiğin kültürden bağımsız olarak geliştiği düşüncesi ise etnomatematiğin gelişme sürecini olumsuz etkilemiştir (Gerdes, 2001).

Etnomatematik terimi, "farklı doğal, sosyal, politik veya kültürel (ethno) çevrelerin karşı karşıya kaldıkları realite (mathema) hakkında bilgi edinmek, onu anlamak, açıklamak, yönetebilmek için kullandıkları yöntem ve teknikler (tics) olarak" tanımlanmıştır (D'Ambrosio, 2018, s.231). Toplumların kültürel bağlamlarında gömülü olan matematiksel düşüncelerin ve faaliyetlerin incelendiği alan etnomatematik olarak adlandırılmaktadır (Gerdes, 2001). Etnomatematik, tüm kültürlerin kendilerine özgü geliştirdikleri matematiksel fikir, düşünce ve uygulamaları içermektedir (Ascher, 1994; Barton, 1996). Etnomatematik yaklaşımı ilk ortaya çıkışında her ne kadar eski yöntemleri ya da geride kalmış düşünceleri ortaya çıkarma amacı taşısa da zamanla günümüzde kullanılan matematiğin bir parçası olmuştur (Gerdes, 1994). Bishop (1991) kültürlerin matematiksel faaliyetlerini sayma, yer belirleme, ölçme, tasarlama, oynama ve açıklama olmak üzere altı temel düşünce etrafinda toplamıştır. Ayrıca Bishop (1991) matematiksel kavram ve ilişkilerin bu düşünceler ile ortaya çıktığını savunmuştur. Örneğin, sayma düşüncesinin altında sayılar, sayı örüntüleri, sayı sistemleri; yer belirleme düşüncesinin altında koordinatların gelişimi, geometrik yer; tasarlama düşüncesinin altında cisimlerin özellikleri, şekli, benzerlik vb. gibi durumları belirlemiştir. Nitekim etnomatematik alanında yapılan ilk çalışmalarda okuma yazma bilmeyen ilkel bireylerin yaptığı bu matematiksel faaliyetleri ele alınmıştır (Francois ve Kerkhove, 2010). Sonrasında ise sayılar, örüntü, fraktal, olasılık, cebir gibi birçok matematiksel kavram ya da alan etnomatematiğe konu olmuştur. Bu süreçte D'Ambrosio, Ascher ve Gerdes gibi araştırmacılar önderliğinde yapılan çalış̧ malar ile etnomatematik, kültür ve matematik arasındaki ilişkiyi detaylıca ele alarak günümüzdeki halini almıştır.

Matematik eğitimi alanında etnomatematik ile ilgili okul öncesi düzeyinden başlayarak yükseköğretim düzeyine kadar her yaş aralığında çalışma grupları ile nicel ve nitel araştırma yöntemleri kullanılarak araştırmalar yapılmıştır. Bu çalışmalarda etnomatematik, başarıyı artıran (Magallanes, 2003), matematiksel anlama yeteneğini geliştiren (Widada, Herewaty ve Lubis, 2018), matematiksel düşünme becerilerini geliştiren (Iluno ve Taylor, 2013; Powell ve Temple, 2001) ve matematiğe yönelik olumlu tutum oluşturan (Aktuna, 2013; Kara, 2009) bir alan olarak görülmektedir. Bununla birlikte etnomatematik öğrencilerin kültürün matematikten kopuk olmadığını görmelerine ve kültürel farkındalık kazanmalarına yardımcı olmaktadır (Bishop, 1991; Zaslavsky, 1998).

Matematiğin, insanların ihtiyaçlarını karşılama amacıyla ortaya çıktığının ve günlük hayatta ihtiyaçları karşılamak amacıyla kullanıldığının fark edilmesi önemlidir. Bu farkındalık sürecine matematik ile kültür arasındaki ilişkinin anlamlandırılması olumlu katkı yapacaktır. Öyle ki sahip olunan kültürel değerler, kültürel bilgiler ve kültürel düşünme süreçleri ile okul matematiği kapsamında öğrenilen matematiksel bilgi ve düşünme süreçleri birbirini tamamlamaktadır (Güreş, 2019). Bu nedenle matematik derslerinde kültür ve matematik arasındaki ilişkiyi ortaya koyabilecek etnomatematik uygulamalara yer verilmesi önem kazanmaktadır. Matematik öğretmenlerinin matematik ve kültür arasındaki ilişkiyi sınıf ortamına yansıtma noktasında eksik olduğu görülmüştür (Lewis, 2016). Öğretmenlerin bu eksikliği, öğrencilerin matematik başarısını olumsuz etkilemekte, kendi kültürleri ile matematik arasında etkileşim olmadığını düşünmelerine ve rol model ilişkisi kuramamalarına neden olmaktadır (d'Entremont, 2015; Krummel, 2013). Ayrıca öğretmenlerin tecrübe, materyal ve pedagoji eksiklikleri nedeniyle yeterli etnomatematik bilgisine sahip olmadıkları da görülmüştür. $\mathrm{Bu}$ eksikliklerin giderilmesi için etnomatematiğin matematik öğretim programlarına gömülü bir şekilde uygulanması gerekliliği önerilmiştir (Kang, 1992).

Ülkemizde öğretim programlarında yer alan Türkiye Yeterlilikler Çerçevesine göre "Kültürel farkındalık ve ifade" öğrencilerin sahip olması beklenilen yetkinlikler arasında gösterilmektedir (Milli Eğitim Bakanlığı [MEB], 2018) ki etnomatematik yardımı ile bu yetkinlik geliştirilebilir. Ayrıca Yüksek Öğretim Kurulu [YÖK] tarafindan 2018 yllında güncellenen Yeni Öğretmen Yetiştirme Lisans Programları çerçevesinde İlköğretim Matematik Öğretmenliği Programı'nda "Kültür ve Matematik" dersine yer vermiştir. Alan seçmeli olarak okutulması planlanan bu dersin içeriğinde matematik ve kültür ilişkisi, etnomatematik alanında yapılan araştırmaların temel prensipleri, sınıf içi uygulamalara etnomatematik çalışmalarını dâhil etmenin önemi ve 
farklı kültürel bağlamlara yönelik sınıf içi matematik etkinlikleri tasarlama gibi konulara yer verilmiştir. Kültür ve Matematik dersinin amacı ve içeriği dikkate alındığında, etnomatematiğin anlamına, önemine ve sınıf içerisinde kullanımına vurgu yaptığı görülmektedir.

Alanyazın incelendiğinde uluslararası düzeyde etnomatematik alanında yapılan çalışmalar olsa da ülkemizde bu alanda yapılan çalışmaların sayısının çok az olduğu ifade edilmektedir (Güreş, 2019). Ülkemizde yapılan çalışmalar birkaç lisansüstü tez, makale, bildiri ve kitap çevirisi ile sınırlı kalmıştır. Kendi kültürlerine ait öğeler ile zenginleştirilmiş ders içerikleri aracılığıyla yapılan matematik öğretiminin öğrencilerin matematiksel kavramları nasıl algıladıkları ve ilişkilendirdiklerinin (Aktuna, 2013), bu süreci nasıl yorumladıkları ve etkinliklere nasıl katıldıklarının (Sevgi, 2019; Yılmaz, Öztürk ve Kanbolat, 2012) farklı kültürel değerlere sahip olan öğrencilerin matematiksel düşüncelerinin (Güreş, 2019) incelendiği nitel paradigmaya sahip çalışmaların yanı sıra etnomatematiğin akademik başarı ve matematiğe karşı tutum üzerindeki etkilerinin incelendiği deneysel çalışmalar (Kara, 2009) da yapılmıştır. Göreceli olarak yeni bir araştırma sahası olarak kabul edilen etnomatematik ile ilgili ülkemizde bu denli az çalışma yapılması kültürümüz ile matematik eğitimi arasındaki ilişkinin yeteri kadar ortaya konulmadığı şeklinde yorumlanabilir.

$\mathrm{Bu}$ araştırmada, etnomatematik etkinliklerin ilköğretim matematik öğretmen adayları tarafından tasarlanmasının öğretmen adayı boyutunda, tasarlanan etkinliklerin sınıf ortamında uygulanmasının öğretmen adayı, öğrenci ve öğretmen boyutlarında incelenmesi ve ilköğretim matematik öğretmen adayları ve öğretmenlerin etnomatematiğe yönelik farkındalık, önceki öğrenme ve mesleki hayatta kullanım durumlarının belirlenmesi amaçlanmıştır. Bu amaç doğrultusunda araştırma sürecinde aşağıdaki sorulara cevap aranmıştır.

- İlköğretim matematik öğretmen adaylarının etnomatematik etkinliklerinin tasarlama sürecinin ve uygulama sürecinin avantajları ve dezavantajları nasıldır?

- İlköğretim matematik öğretmen adaylarının ve öğretmenlerinin etnomatematiğe yönelik farkındalık, önceki öğrenme ve mesleki hayatta kullanım durumları nasıldır?

- Etnomatematik etkinlikleri ile yürütülen matematik derslerine öğrencilerin bakış açısı nasıldır?

$\mathrm{Bu}$ araştırma ile matematik ve kültür arasındaki ilişkinin teorik ve pratik anlamda yansımalarının ortaya konmasıyla öğretmenlerin ve öğretmen adaylarının etnomatematiğe yönelik farkındalığının artacağ düşünülmektedir ki bu da araştırmanın güçlü yönü olarak görülmektedir. Bununla birlikte tasarlanan etnomatematik etkinlikleri matematik öğretmenleri ve öğretmen adayları için sınıf içerisinde kullanılabilecek örnek teşkil edecektir. Ayrıca ülkemizde etnomatematik alanında yapılan çalışma sayısının azlığı dikkate alındığında bu araştırmanın etnomatematik alanyazınına katkı sağlayacağı düşünülmektedir.

\subsection{Kuramsal Çerçeve}

Bu araştırmada D'Ambrosio tarafından ortaya konan etnomatematik yaklaşımı kuramsal çerçeve olarak kabul edilmiştir. Bu kuramsal çerçeveye göre okul matematiğinin en önemli amacı öğrencilerin içinde bulundukları kültürde var olan matematiksel düşüncelerin farkında olmalarını, matematiği günlük hayatın bir parçası olarak görebilmelerini ve böylelikle kültürlerine değer vermelerini sağlamak olmalıdır. Bu farkındalık ve bilincin diğer bilişsel becerileri beraberinde getireceği savunulmaktadır (D’Ambrosio ve Rosa, 2017).

Matematiğe kültürel antropoloji bakış açısıyla yaklaşan ve matematik ile kültürün ilişkisini sorgulayan etnomatematik yaklaşımı matematiğin kültürden bağımsız olarak görüldüğü genel kanının aksini savunmaktadır (Stathopoulou, Kotarinou ve Appelbaum, 2015). Bu yaklaşımın mahiyetini matematiksel bilginin farklı kültürel çevreler içerisinde nasıl süreçlerden geçerek oluştuğu, düzenlendiği ve nasıl yayıldığını anlamak oluşturmaktadır (D’Ambrosio, 2007). Öğrenciler de okula sahip oldukları değerleri, normları ve kavramları beraberinde getirirler. Dolayısıyla öğrenme ortamları parçası oldukları kültürden ayrı düşünülmemelidir (Adam, 2004). Öğrencilerin sahip oldukları kültürü oluşturan değer, norm ve kavramlardan bazıları da matematikseldir (Bishop, 1994). Kültürel öğelerin matematik öğretim programında yer almasını öneren etnomatematik yaklaşımı bireylerin modern dünyada etkin rol alabilmeleri için gerekli olan akademik matematiğin öğrencilerin kültürlerinde var olan matematiksel öğelerle zenginleştirilmiş içeriklerle sunulmasını önermektedir (D’Ambrosio, 2001). Öğrencilerde matematiğin kültürlerinden bağımsız, soyut bir bilim olduğu algısı oluşturmadan, matematik öğrenme ortamları kendi kültür ve medeniyetlerinin önemli bir parçası olduğunu görmelerini sağlayacak şekilde düzenlenmelidir (Baki, 2014).

\section{Yöntem}

$\mathrm{Bu}$ araştırmanın amacına uygun olarak nitel araştırma yöntemi ile yürütülmesi planlanmıştır. Araştırmanın deseni çoklu durum çalışması (Yin, 1994) olarak belirlenmiştir. Araştırmada etnomatematik etkinliklerinin tasarlanması, tasarlanan etkinliklerin sınıf içerisinde uygulanma durumları ve öğretmen adayı ve öğretmenlerin etnomatematiğe yönelik farkındalık, önceki öğrenme ve mesleki hayatta kullanım durumları ayrı ayrı birer durum olarak kabul edilmiş; bu durumlar öğretmen adayı, öğrenci ve öğretmen boyutlarında detaylıca incelenmiştir. 


\section{1. Çalışma Grubu}

$\mathrm{Bu}$ araştırmada etnomatematik etkinliklerinin tasarlanması ve uygulanması durumlarına ilişkin derinlemesine bir inceleme yapılması amaçlandığından çalışma grubunun seçiminde amaçlı örnekleme tekniği kullanılmıştır (Patton, 1990). Araştırmanın çalı̧̧ma grubunda 28 öğretmen adayı, 71 öğrenci ve 2 öğretmen yer almaktadır. Öğretmen adayları bir devlet üniversitesinin eğitim fakültesinde ilköğretim matematik öğretmenliği programında öğrenim görmekte, çalı̧̧ma sırasında 22 tanesi (3. dönemde) "Kültür ve Matematik" dersini, 6 tanesi de (7. dönemde) "Öğretmenlik Uygulaması I" dersini almaktadır. Öğrenciler çalışma sırasında 8. sınıf öğrencisi olup, iki farklı devlet ortaokulunun üç şubesinde öğrenim görmektedir. Öğretmenlerin ise biri 5 senedir diğeri 19 senedir matematik öğretmeni olarak görev yapmaktadır. Araştırmanın bundan sonraki bölümünde Kültür ve Matematik dersini alan öğretmen adayları ders sürecinde etnomatematik etkinlikler tasarladıkları için tasarım yapan öğretmen adayları [TÖA], Öğretmenlik Uygulaması I dersini alan öğretmen adayları sınıf ortamında uygulama yaptıklarından uygulama yapan öğretmen adayları [UÖA], 5 senedir görev yapan öğretmen $\ddot{O}_{1}$ ve diğer matematik öğretmeni ise $\mathrm{O}_{2}$ olarak belirtilmiştir.

\subsection{Veri Toplama Araçları}

Araştırmanın veri toplama araçlarını öğretmen adaylarının tasarladığı etkinlikler, öğretmen adayı, öğrenci ve öğretmenlere uygulanan yazılı görüss formları ile araştırmacı alan notları oluşturmaktadır. Ayrıca görüş formlarından elde edilen verilere ilişkin derinlemesine bilgi edinebilmek amacıyla yarı yapılandırılmış görüşmelerden de faydalanılmıştır.

\subsubsection{Etkinlikler}

Öğretmen adayları birinci araştırmacının yürütttüğü "Kültür ve Matematik" dersinde matematik ve kültür arasındaki ilişkiyi aktarabilecek etnomatematik etkinlikleri tasarlamışlardır. $\mathrm{Bu}$ etkinlikler "Öğretmenlik Uygulaması I" dersini alan öğretmen adayları ile değerlendirilerek çeşitli düzenlemeler yapılmış ve sınıf içerisinde uygulanabilecek hale getirilmiştir. "Kültür ve Matematik" dersinde öğretmen adaylarının kendi istekleri ile oluşturdukları 2-3 kişilik gruplar ile toplamda 9 tane etkinlik tasarlanmıştır. Tasarlanan etkinliklerin yapısı ve matematik dersi öğretim programında yer alan konular ve uygulama koşulları dikkate alınarak yapılan değerlendirmeler sonucunda iki tanesi sınıf ortamında uygulanmıştır.

\subsubsection{Yazılı Görüş Formları}

Etnomatematik etkinliklerinin tasarlanması ve sınıf ortamında uygulanması sürecinde öğretmen adayı, öğretmen ve öğrenci düşünceleri görüş formları ile toplanmıştır. Araştırma sürecinde farklı zamanlarda toplamda altı tane görüş formu kullanılmış ve bu görüş formlarının tamamı Tablo 1'de verilmiştir. Görüş formlarında matematik ve kültür arasındaki ilişkiye yönelik farkındalık, önceki öğrenmeler, etkinliklerin tasarlanması ve uygulanması durumlarının öğretme ve öğrenme sürecinde değerlendirilmesi gibi konulara ilişkin sorular yer almaktadır. Görüş formlarının oluşturulması sürecinde (biri matematik eğitimi alanında doktorasını tamamlamış ve diğeri eğitimde kültür ve değerler ile ilgili çalışmalar yapan) iki uzmana araştırma amacı anlatılarak uzman görüşü almak için başvurulmuştur. Uzmanlardan gelen geri bildirimler doğrultusunda görüş formları uygulamaya hazır hale getirilmiştir.

Tablo 1. Yazılı görüş formları, temel sorular ve kullanım amacı

\begin{tabular}{|c|c|c|}
\hline Form & Temel Sorular & Amaç \\
\hline $\mathrm{F}_{1}$ & $\begin{array}{l}\text { Sizin de yer aldığınız matematik öğretmenlerinin katıldığı bir sabah kahvaltısında bir } \\
\text { matematik öğretmeni "Matematik ve kültür aralarında ortak noktası olmayan } \\
\text { birbirinden farklı alanlardır" düşüncesini savunmaktadır. Bu düşünceye katılır } \\
\text { mısınız? Cevabınızı gerekçeleriyle anlatınız. }\end{array}$ & Farkındalık \\
\hline $\mathrm{F}_{2}$ & $\begin{array}{l}\text { Bundan önceki eğitim-öğretim hayatınızda etnomatematik ile ilgili herhangi bir } \\
\text { öğretim süreci veya bilgi/farkındalık oluşturacak bir ortamda bulundunuz mu? } \\
\text { /Ortam oluşturdunuz mu? Bu durumu yeterlilik/nedenler/katkılar vb. açılardan } \\
\text { değerlendiriniz. }\end{array}$ & $\begin{array}{c}\text { Önceki } \\
\text { Ögrrenmeler }\end{array}$ \\
\hline $\mathrm{F}_{3}$ & $\begin{array}{l}\text { Tasarladığınız etkinliği düş̧ünerek bu tasarlama sürecinin size olumlu ve olumsuz } \\
\text { durumlarını (katkı-fayda, zarar vb.) detaylıca açıklayınız. } \\
\text { Tasarlama sürecinde sizi zorlayan durumları ifade ediniz. }\end{array}$ & $\begin{array}{c}\text { Tasarlama } \\
\text { Süreci } \\
\text { Değerlendirme }\end{array}$ \\
\hline
\end{tabular}


Tablo 1'in devamı

\begin{tabular}{|c|c|c|}
\hline Form & Temel Sorular & Amaç \\
\hline $\mathrm{F}_{4}$ & $\begin{array}{l}\text { Uygulanan etkinliğin avantajlarını ve dezavantajlarını açıklayınız. } \\
\text { Uygulanan etkinliğin verimliliğini değerlendiriniz. (1-10 arası puanlama ve (var ise) } \\
\text { açıklama) } \\
\text { - Matematiksel Kavram/Konu Öğretimi açısından } \\
\text { - Kültür Aktarımı açısından } \\
\text { - Öğrencilerin Matematik Öğrenimi açısından } \\
\text { - Sinıf Yönetimi açısından } \\
\text { - Öğrencilerin Derse İlgisi açısından } \\
\text { - Sizin Etkinliğe Yaklaşımınız açısından }\end{array}$ & $\begin{array}{l}\text { Uygulama } \\
\text { Süreci } \\
\text { Değerlendirme }\end{array}$ \\
\hline $\mathrm{F}_{5}$ & $\begin{array}{l}\text { Etnomatematik etkinliklerinin olası avantajları ve dezavantajları hakkında bilgi veriniz. } \\
\text { Matematik öğretmeni olarak göreve başladığınızda/öğretmenlik hayatınızda/bundan } \\
\text { sonraki derslerinizde matematik ve kültür ile ilişkili etkinlikleri derslerinizde } \\
\text { kullanmayı düşünüyor musunuz? Cevabınızı detaylıca açıklayınız. }\end{array}$ & $\begin{array}{c}\text { Mesleki Hayatta } \\
\text { Kullanım }\end{array}$ \\
\hline $\mathrm{F}_{6}$ & $\begin{array}{l}\text { Daha önce matematik derslerinde kültürümüz ile ilgili etkinlik yaptınız mı? } \\
\text { Bundan sonraki matematik derslerinde kültürümüz ile ilişkili etkinlikler yapmak ister } \\
\text { misiniz? } \\
\text { Bu etkinliğe } 1 \text { ile } 10 \text { arasında kaç puan verirsiniz? } \\
\text { Etkinlik sayesinde neler öğrendiniz? Lütfen detaylıca açılayınız. } \\
\text { Etkinliğe ilişkin önerileriniz ya da görüşleriniz var mıdır? Var ise lütfen detaylıca } \\
\text { açıklayınız. }\end{array}$ & $\begin{array}{c}\text { Öğrenci } \\
\text { Değerlendirmesi }\end{array}$ \\
\hline
\end{tabular}

2.2.3. Araştırmacı Alan Notları: Araştırmanın nitel bir çalışma olması nedeniyle araştırmacı rolü önem kazanmaktadır. Etnomatematik etkinliklerinin tasarlanması ve sınıf ortamında uygulanması sürecinde araştırmacılar gözlemlerde bulunmuşlar, dikkat çeken durumları, anlık görüşmeleri, çeşitli değerlendirmeleri not almışlardır. Alınan bu notlar bulguların çeşitlendirilmesine katkı sağlamış ve bulguların yorumlanması sürecine derinlik kazandırmıştır.

2.2.4. Yarı Yapılandırılmış Görüşme Formu: Öğretmen adayları ile yazılı görüş formlarından elde edilen verilerin detaylandırılması, yazılı ifadelerin arkasında yatan nedenlerin sorgulanması amaciyla yarı yapılandırılmış görüşmeler [YYG] yapılmıştır. Görüşme yapılan öğretmen adayları belirlenirken veri çeşitliliğ sağlaması açısından hazırlık aşaması öncesinde matematik ve kültür arasında ilişkiye yönelik düşünceleri (ilişki vardır/ yoktur) ile tasarladıkları/ uyguladıkları etkinlikler belirleyici olmuştur. Bu bağlamda 2 tane TÖA ve 2 tane UÖA belirlenmiş olup, YYG yapılan öğretmen adaylarına ilişkin bilgiler Tablo 2'de verilmiştir.

Tablo 2. Yarı yapılandırılmış görüşme yapılan öğretmen adaylarına ilişkin bilgiler

\begin{tabular}{ccc}
\hline Katılımcı & Matematik ve Kültür Arasında İlişki & Tasarlanan/Uygulanan Etkinlikler \\
\hline TÖA $_{1}$ & Yoktur & Kanaviçe ile İç İçe \\
\hline TÖA $_{2}$ & Vardır & DallıMat \\
\hline UÖA $_{1}$ & Yoktur & MatKül \\
\hline UÖA $_{2}$ & Vardır & Kanaviçe ile İçe Ice \\
\hline
\end{tabular}

Öğretmen adaylarına görüş formlarındaki sorulara vermiş olduğu cevaplar hatırlatılarak/gösterilerek farklı düşüncelere sahip olup olmadıkları sorulmuş ve görüşlerini detaylandırmaları istenmiştir.

\subsection{Veri Toplama Süreci}

Araştırmanın veri toplama sürecinde aşamalı bir yapı izlenmiştir. Bu süreç hazırlık, tasarım ve uygulama olmak üzere üç aşamada gerçekleştirilmiştir (Tablo 3).

Tablo 3. Veri toplama süreci akışı

\begin{tabular}{|c|c|c|c|c|c|c|c|c|}
\hline 1. Adım & 2. Adım & 3. Adım & 4. Adım & 5. Adım & 6. Adım & 7. Adım & 8. Adım & 9. Adım \\
\hline $\mathrm{F}_{1}$ & \multirow{2}{*}{$\begin{array}{l}\text { Hazırlık } \\
\text { Aşamas1 }\end{array}$} & $\mathrm{F}_{2}$ & \multirow{2}{*}{$\begin{array}{l}\text { Tasarım } \\
\text { Aşaması }\end{array}$} & $\mathrm{F}_{3}$ & \multirow{2}{*}{$\begin{array}{c}\text { Uygulama } \\
\text { Aşaması }\end{array}$} & $\mathrm{F}_{4}$ & $\mathrm{~F}_{6}$ & $\mathrm{~F}_{1}-\mathrm{F}_{5}-\mathrm{YYG}_{1}$ \\
\hline $\begin{array}{c}\text { TÖA, UÖA, } \\
\text { Öğretmen }\end{array}$ & & $\begin{array}{c}\text { TÖA, UÖA, } \\
\text { Öğretmen }\end{array}$ & & TÖA & & $\begin{array}{c}\text { UÖA, } \\
\text { Öğretmen }\end{array}$ & Öğrenci & $\begin{array}{c}\text { TÖA, UÖA, } \\
\text { Öğretmen }\end{array}$ \\
\hline
\end{tabular}

Hazırlık aşaması öncesinde, matematik ve kültür ilişkisi hakkındaki bilgi ve düşüncelerini öğrenebilmek amacıyla öğretmen adaylarına ve öğretmenlere Görüş Formu $1\left[F_{1}\right]$ uygulanmıştır. $F_{1}$ 'in uygulanmasının ardından hazırlık aşamasında öğretmen adaylarına "Kültür ve Matematik" dersi akışı çerçevesinde (Tablo 4) matematik ve kültür ilişkisi, kavramlar ile kültürel bağlamları, etnomatematik alanında yapılan araştırmalar ve temel prensipleri, sınıf içi uygulamalara etnomatematik çalışmalarını dâhil etmenin önemi aktarılmıştır. UÖA'ya 
ve öğretmenlere de benzer akış çerçevesinde öncelikle matematik ve kültür ilişkisi, kavramların kültürel bağlamları aktarılmış, etnomatematik araştırmalar ve sınıf içerişinde etnomatematik uygulamalar hakkında soru cevap yöntemi ile kısa açıklamalar yapılmıştır.

Tablo 4. Kültür ve Matematik dersi akışı

Kültürün tanımı, kültür ve matematik arasındaki ilişki

Kültürel ögeler ile matematiksel bağlamlar (Ercan, 2005)

- Sayılar, şekiller, simgeler, kumda çizilen şekiller, akrabalık ilişkilerinin mantığı

Etnomatematik tanımı ve etnomatematik alanında yapılan araştırmalar

Sınıf içi uygulamalarda etnomatematik kullanımı

Etnomatematik etkinlikler

- Yörük Çadırları (Güreş, 2019), Selçuklu Kümbetleri (Baki, 2014)

Etnomatematik etkinlik tasarımı

Hazırlık aşaması sonrasında etnomatematik ile ilişkili önceki öğrenmeleri/tecrübeleri hakkında bilgi edinmek amacıyla öğretmen adaylarına ve öğretmenlere Görüş Formu $2\left[\mathrm{~F}_{2}\right]$ uygulanmış ve tasarım aşamasına geçilmiştir. Tasarım sürecinde TÖA'dan kültürümüze ilişkin sınıf içi matematik etkinlikleri tasarlamaları istenmiştir. $\mathrm{Bu}$ süreçte araştırmacılar ile TÖA haftalık görüşmeler gerçekleştirmişler ve etkinlik tasarlama prensipleri hakkında bilgilendirilmişlerdir. TÖA öncelikle kültürümüz ile ilişkili oluşturulabilecek etkinlikler hakkında araştırma yapmışlar ve çeşitli fikirler oluşturmuşlardır. Ardından tasarlanan etkinlikleri matematik dersi öğretim programında yer alan konu ve kazanımlar ile ilişkilendirmişler ve etkinliğin uygulanması sürecinde ortaya çıkacak olası sorunları ve çözüm önerilerini belirlemişlerdir. Çalışmalar yaklaşık 5 haftalık süre sonunda tamamlanmış ve 9 farklı etkinlik tasarlanmıştır. Tasarlama aşamasının sonrasında TÖA'ya tasarlama sürecinin değerlendirebilmesi amacıyla Görüş Formu $3\left[\mathrm{~F}_{3}\right]$ uygulanmıştır.

$\mathrm{F}_{3}$ 'ün uygulanmasının ardından tasarlanan etkinlikler UÖA'nın da yer aldığı etkinlik sunum dersinde tanıtılmıştır. Tanıtım sürecinde öğretmen adaylarının etkinlik hakkındaki görüşlerinden yararlanılarak etkinliklere son hali verilmiştir. Kanaviçe ile İç İçe ve MatKül etkinliklerinin sınıf ortamında uygulanmasına karar verilmiştir. Kareköklü ifadeler konusu ile ilişkili MatKül etkinliğinin (EK1) 8. sınıf matematik dersinde, dönüşüm geometrisi, eşitlik ve denklem ve veri analizi konuları ile ilişkili Kanaviçe ile İç İçe etkinliğinin (EK2) ise yine 8. sınıf Matematik Uygulamaları dersinde uygulanmasına karar verilmiştir. Tasarım sürecinin tamamlanmasının ardından uygulama sürecine geçilmiştir. Uygulanan etkinliklere ilişkin kısa bilgilendirmeler ekler bölümünde yapılmıştır.

UÖA uygulama sürecinde uygulanacak etkinliklere yönelik ders planları hazırlamışlardır. Hazırlanan ders planları araştırmacılar ile yapılan görüşmelerde incelenmiş ve uygulamaya hazır hale getirilmiştir. Kanaviçe ile İç İçe etkinliği için 2 ders saati, MatKül Etkinliği için ise 1 ders saati ayrılmıştır. Etkinlikler uygulanırken araştırmacılardan biri, ders öğretmeni ve iki tane öğretmen adayı gözlemci olarak sınıflarda bulunmuşlardır.

Uygulama sonrasında; UÖA'ya ve öğretmenlere uygulama sürecini ve etkinlikleri değerlendirmeleri amaciyla Görüş Formu $4\left[\mathrm{~F}_{4}\right]$, öğrencilere ders sürecini ve etkinliği değerlendirmeye yönelik görüşlerini belirlemek amacıyla Görüş Formu $6\left[\mathrm{~F}_{6}\right]$ uygulanmıştır. Ardından, UÖA ve TÖA bir araya getirilerek uygulama süreci hakkında TÖA'na bilgilendirmelerde bulunulmuştur. Son olarak öğretmen adaylarının ve öğretmenlerin matematik ve kültür ilişkisi hakkındaki bilgi ve düşüncelerindeki değişimleri belirleyebilmek amacıyla $F_{1}$ ve etnomatematik etkinliklerinin mesleki hayatta kullanımına ilişkin düşüncelerini belirleyebilmek amacıyla Görüş Formu $5\left[\mathrm{~F}_{5}\right]$ uygulanmıştır. Ayrıca öğretmen adaylarının tasarlanan ve uygulanan etkinliklere yönelik düşüncelerini detaylandırmak amacıyla YYG gerçekleştirilmiştir.

\subsection{Verilerin Analizi}

Araştırma sürecinde tasarlanan etkinlikler öğretim programı (ilgili konular, önceki öğrenmeler) ve materyal kullanımı bağlamlarında analiz edilmiştir. Görüşme formlarından elde edilen veriler ise formlarda yer alan soruların özelliklerine göre kodlar ve kategoriler oluşturularak analiz edilmiştir. Örneğin $F_{3}$ ’ten elde edilen veriler etnomatematik etkinlikleri tasarlama süreci için katk1-fayda, zarar ve zorlayan durumlar, $F_{4}$ 'ten elde edilen veriler etnomatematik etkinlikleri uygulama süreci için avantaj ve dezavantaj gibi kategorilere ayrılmış kategorilere ilişkin kodlar verilmiş ve frekanslar ile sunulmuştur. Bununla birlikte bulgular bölümünde akıcılığın sağlanabilmesi amacıyla çalışma grubundan elde edilen verilerin bir kısmı doğrudan bir kısmı ise transkript edilerek verilmiştir.

\subsection{Araştırmanın Geçerliği ve Güvenirliği}

Nitel yöntemli araştırmalarda iç geçerlik yerine "inandırıcılık", dış geçerlik yerine "aktarılabilirlik" kavramları karşılık gelmektedir (Lincoln ve Guba, 1985). Araştırmacı ile veri kaynağı arasında oluşturulan etkileşimin geniş bir zamana yayılması araştırma verilerinin inandırıcılığını artırmaktadır (Yıldırım ve Şimşek, 2013). Bu çalışmada da araştırmacılar ve katılımcılar bir dönem boyunca etkileşim halinde olmuşlardır. Nitel 
araştırmada olay ve olgular derinlemesine ve ayrıntılı bir şekilde incelendiği için genelleme mümkün değildir ancak sonuçlar benzer ortamlara aktarılabilir. Bu çalışmada araştırma süreci açık, net ve ayrıntılı bir şekilde tanımlanmıştır. Ayrıca, veri çeşitlemesi ve araştırmacı üçgenlemesi kullanılmıştır. Veri çeşitlemesi için çalışmada görüş formları, araştırmacı alan notları ve yarı yapılandırılmış görüşme formları olmak üzere birden fazla veri kaynağı kullanılmış ve sonuçları karşılaştırılmıştır. Araştırmacı üçgenlemesi ile verilerin toplanmasında, analizinde ve yorumlanmasında birden fazla araştırmacı yer almıştır. Ayrıca görüsşme formlarının analizi bireysel olarak araştırmacılar tarafından yapılmış ve kod örnekleri ve kategoriler araştırmacıların uzun süreli toplantılarında fikir birlikleri ile belirlenmiştir.

\section{Bulgular}

Araştırmanın bulguları üç bölümde sunulmuştur. Birinci bölümde tasarlanan etkinliklere, tasarlama ve uygulama sürecine yönelik bulgular, ikinci bölümde öğretmen adayları ve öğretmenlerin matematik ve kültür ilişkisi farkındalığına, önceki öğrenmelerine ve mesleki hayatta kullanımına yönelik bulgulara yer verilmiştir. Son bölümde ise öğrencilerin uygulama sürecini değerlendirmesine yönelik bulgulara yer verilmiştir.

\subsection{Tasarlanan Etkinliklere, Tasarlama ve Uygulama Sürecine Yönelik Bulgular}

Araştırma sürecinde öğretmen adayları tarafından dokuz tane etkinlik tasarlanmıştır. Tasarlanan etkinlikler ilişkili konular, önceki öğrenmeler ve materyal kullanımı bağlamlarında analiz edilmiştir (Tablo 5).

Tablo 5. Tasarlanan etkinlikler ve etkinliklere ilişsin bilgiler

\begin{tabular}{lccc}
\hline Etkinlik Adı & İlişkili Konular & Önceki Öğrenmeler & Materyal \\
\hline Kanaviçe ile İç İçe & Dönüşüm Geometrisi & Denklemler/İstatistik & A4 Çizim \\
\hline DallıMat & Dönüşüm Geometrisi & Oran/Orant1 & Mukavva Kesim-Çizim \\
\hline Cami & Çevre-Alan Hesabı & Oran/Orantı & Somut Materyal \\
\hline Zeybek & Dönüşüm Geometrisi & Koordinat Sistemi & Uygulamalı Gösterim \\
\hline Tarihi Kapı & Dönüşüm Geometrisi & - & Elişi Kağıtları-GeoGebra \\
\hline Mangala & Olasılık & - & Somut Materyal \\
\hline Motifler & Dönüşüm Geometrisi & - & Elişi Kağı̆tları \\
\hline MatKül & Bu araştırmada kareköklü sayılar ile ilişkilidir ancak farklı & konular ile de ilişkili olabilir. & Oyun \\
\hline EtnoModelleme & $\begin{array}{c}\text { Bu araştırmada cebir öğrenme alanına ilişkin konular ile } \\
\text { ilişkilidir ancak farklı konular ile de ilişkili olabilir. }\end{array}$ & \multirow{2}{*}{ A4 Kâğıdı } \\
\hline
\end{tabular}

Tasarlanan etkinliklerin birçoğunun konusu dönüşüm geometrisi iken bununla birlikte olasılık, geometrik şekiller ve çevre-alan hesabı gibi konuların da olduğu görülmüştür. Bununla birlikte etkinlikler denklemler, istatistik, oran/orant1, koordinat sistemi gibi önceki öğrenmeler ile de ilişkilidir. Etkinliklerin yapımında somut materyal, mukavva ve el işi kâğıdı kullanılmıştır. MatKül ve EtnoModelleme etkinlikleri ise içeriği dolayısıyla her konuda uygulama esnekliğine sahiptir. MatKül etkinliği aşamalı bir oyun mantığına göre düzenlenmiştir. Etkinlikte kültürümüzle ve kareköklü sayılar konusu ile ilişkili sorular yer almaktadır. EtnoModelleme etkinliğinde ise kültürümüz ile ilişkili açıklayıcı bilgiler ve bu bilgilere ilişkin matematiksel modelleme soruları yer almaktadır.

Etkinlik tasarlama süreçlerinde TÖA'nın basılı ve çevrimiçi olarak bulunan makale, tez gibi akademik kaynaklara kütüphanede ulaşamadıkları ve genellikle Google akademik arama motoru ve çeşitli sosyal medya uygulamalarından faydalandıkları araştırmacı alan notlarında yer almıştır. Ayrıca "Zeybek" etkinliğini tasarlayan öğretmen adaylarından bir tanesinin zeybek oyununu iyi bilmesinin ve "Tarihi Kapı" etkinliğini tasarlayan öğretmen adaylarından bir tanesinin de GeoGebra uygulamasına özel ilgisinin olmasının bu etkinlikleri seçmelerinde yönlendirici olduğu araştırmacı alan notlarında yer almıştır.

Etkinlik tasarlama sürecinin değerlendirilmesi amacıyla $\mathrm{F}_{3}$ 'e verilen cevaplar; olumlu görüşler (katkı-fayda) ve olumsuz görüşler (zorluklar) olarak analiz edilmiştir (Tablo 6).

Tablo 6. Etnomatematik etkinlikler tasarlama sürecinin katkı-fayda ve zorlukları

\begin{tabular}{|c|c|c|}
\hline Kategori & Olumlu Görüșler & $\mathbf{f}$ \\
\hline \multirow{6}{*}{$\begin{array}{l}\text { Katkı } \\
\text { Fayda }\end{array}$} & Kültürümüz ve kültürel ögelere ilişkin araștırma yapmayı öğrendim/bilgi sahibi oldum. & 21 \\
\hline & Kültürümüzün matematik ile iç içe olduğunu fark ettim. & 20 \\
\hline & $\begin{array}{l}\text { Bir matematik konusunu kültürel bir öge ile ilişkilendirerek nasıl aktarabileceğimi } \\
\text { öğrendim. }\end{array}$ & 15 \\
\hline & $\begin{array}{l}\text { Matematik dersi ögretim programında yer alan konu-kazanım vb. hakkında bilgi sahibi } \\
\text { oldum. }\end{array}$ & 21 \\
\hline & Etkinlik tasarlama süreci hakkında tecrübe edindim. & 17 \\
\hline & Grup çalışmasının önemli olduğunu anladım. & 8 \\
\hline
\end{tabular}


Tablo 6'nın devamı

\begin{tabular}{lll}
\hline & Olumsuz Görüşler & f \\
\hline & Nasıl bir etkinlik tasarlayabileceğime karar verme sürecinde zorlandım. & 19 \\
\cline { 2 - 3 } Konu/kazanım ve etkinliği eşleştirme sürecinde zorlandım. & 11 \\
\cline { 2 - 3 } & Etkinliğin sınıf ortamına aktarım sürecini planlamada zorlandım. & 21 \\
\cline { 2 - 3 } & $\begin{array}{l}\text { Etkinliğin tasarımı ve aktarımı sürecinde kullanılan kâğıt, mukavva gibi el becerisi } \\
\text { gerektiren araç-gereç ve materyallerin kullanımında zorlandım. }\end{array}$ & 10 \\
\hline
\end{tabular}

TÖA etnomatematik etkinlikler tasarlama sürecinde "Bu etkinliği hazırlamadan önce kültür ve matematik hakkındaki bağlantıyı kuramaz ve bir iki cümleden fazla olarak anlatamazdım... Bununla beraber kültürü araştırma, tanıma ve yeniden fark etme olanağım oldu." şeklinde düşüncelerini belirterek kültüre ve kültürel ögelere ilişkin araştırma yapmayı öğrendiklerini ve bilgi sahibi olduklarını $(n=21)$ ve kültür ile matematik ilişkisini fark ettiklerini ifade etmişlerdir $(n=20)$. Ayrıca TÖA matematik dersi öğretim programında yer alan konu-kazanım vb. ögeler hakkında bilgi sahibi olmuşlar $(n=21)$ ve etkinlik tasarlama süreci hakkında tecrübe sahibi olduklarını $(\mathrm{n}=17)$ ve matematiği kültürel ögeler ile nasıl aktarabileceklerini öğrendiklerini belirtmişlerdir $(n=15)$. TÖA'nın bir kısmı $(n=8)$ etkinlik tasarlama sürecinde grup çalışmasının önemli olduğunu da ifade etmiştir. TÖA'nın tamamı "kültür ve matematik ile ilişkili böyle etkinlik hazırlamanın olumsuz etkisinin olabileceği fikrine katılmıyorum." şeklinde düşünceler belirterek etkinlik tasarlama sürecinin olumsuz etkisinin ve zararının olmadığını belirtmişlerdir.

Etkinlik tasarlama sürecinde ise TÖA, "Etkinlik planı hazırlarken sınıf içi uygulama kısmını planlamak zordu”, "Etkinlik bağlamında hangi kazanımın uygulanacă̆ını belirlemeye çalışırken zorlandım” gibi düşünceler ile etkinliğe karar verme, etkinliği konu-kazanım ile ilişkilendirme, sınıf ortamına aktarma gibi durumlarda zorlandıklarını ifade etmişlerdir.

Yapılan görüşmelerde ise TÖA $A_{1}$ etkinlik tasarlama sürecinin olumsuz bir etkisinin olmadığını belirtmiş ve matematik derslerinde kültürel bir ögenin kullanılmasının büyük avantaj olduğunu ifade etmiştir. TÖA $\mathrm{A}_{2}$ de etkinlik tasarlama süreci hakkında benzer açıklamalarda bulunmuştur. Ayrıca etkinlik tasarlama süreci hakkında tecrübe edindiğini fakat mukavva kesim ve çizim işlerinde zorlandıklarını ifade etmiştir.

$\mathrm{TÖ}_{2}:$... Etkinliği hazırlamak için çok uğraştık. Çünkü kâğıt ve mukavva kesmek çok zor oldu. Bindallı sürekli bildiğimiz, gördüğ̈̈müz bir şeydi ama matematik dersinde kullanabileceğimizi gördük aslında. Bu konuda çok şaşkınım...

Etkinlik uygulama sürecinin değerlendirilmesi amacıyla UÖA'nın $\mathrm{F}_{4}$ 'e verdikleri cevaplar; uygulanan etkinliklerin avantajları (ders süreci, kültür, matematik) ve dezavantajları (sınıf yönetimi) olarak analiz edilmiş ve Tablo 7'de sunulmuştur.

Tablo 7. Ders sürecinde uygulanan etnomatematik etkinliklerin avantajları ve dezavantajları

\begin{tabular}{lll}
\hline Kategori & Avantajlar & f \\
\hline \multirow{4}{*}{ Ders Süreci } & Öğrencilerin tamamı derse etkin bir şekilde katıldılar. & 4 \\
& Öğrencilerin derse karşı ilgileri arttı. & 5 \\
& Önceki derslere göre motivasyonları yüksekti. & 3 \\
& Daha önceki derslerde söz hakkı almayan öğrenciler söz hakkı almaya başladı. & 4 \\
& Daha fazla öğrenci söz hakkı almak/tahtaya kalkmak istedi. & 5 \\
\hline \multirow{2}{*}{ Kültür } & Kültürümüze ilişkin bilgi sahibi oldular. & 6 \\
& Kültürel ögeleri merak etmeye başladılar. & 4 \\
\hline \multirow{3}{*}{ Matematik } & Kareköklü sayılara ilişkin soruları çözen öğrenci sayısı arttı. & 2 \\
& Dönüşüm geometrisi konusunda motif, süsleme gibi farklı örnekler verdiler. & 2 \\
& Önceki senelerde öğrendikleri konuları tekrardan hatırladılar. & 3 \\
\hline \multirow{2}{*}{ Sınıf } & Dezavantajlar & f \\
\hline \multirow{2}{*}{ Yönetimi } & Sınıf hâkimiyeti konusunda sorun yaşadım. & 6 \\
\cline { 2 - 3 } & Geleneksel oturma düzeninde olması nedeniyle çizimlerde zorlandım. & 3 \\
\cline { 2 - 3 } & Uygulama sürecinde planlayamadığım durumlar (oyun kuralları-sorular) oldu. & 5 \\
\hline
\end{tabular}

UÖA etnomatematik etkinliklerin, öğrencilerin derse yönelik ilgilerinin artması ( $\mathrm{n}=5)$, derse karşı motivasyonlarının yüksek olması $(n=3)$ gibi ders sürecine olumlu etkilerinin olduğunu ifade etmişlerdir. Ayrıca etnomatematik etkinlikler ile öğrencilerin kültürümüze ilişkin bilgi sahibi olduklarını $(n=6)$, kültürel ögeleri merak etmeye başladıklarını $(n=4)$ ve öğrencilerin matematik öğrenme süreçlerine katkıda bulunduklarını $(n=7)$ belirtmişlerdir. Bununla birlikte UÖA, açıklamalarında uygulanan etkinliklerin sınıf hâkimiyeti $(n=6)$ ve uygulama sürecinde çıkan aksaklıklar $(\mathrm{n}=5)$ gibi konularda dezavantaj oluşturduğunu vurgulamıştır. 
Uygulama sürecinde öğretmenlerin $\mathrm{F}_{4}$ 'e verdiği cevaplar incelendiğinde etkinliklerin en önemli avantajının öğrencilerin matematiğe yönelik tutumlarına etkisi olduğunu ifade ettikleri görülmüştür. Ayrıca öğretmenler öğrencilerin kültür hakkında bilgilendirilmesinin ve kültürün matematikle ilişkilendirilmesinin önemli olduğunu ve öğrencilere farklı bakış açısı kazandıracağını da ifade etmişlerdir. Bununla birlikte Ö 2 öğretim programının yoğunluğunun; $\ddot{O}_{1}$ ise kalabalık sınıfların etkinliği uygulamada dezavantaj oluşturacağını belirtmiştir (Şekil 1).

\section{Msfredatton kgnakl, olorak etkinlik sok soron alabilis.}

\section{Ancok sinif lor kalabalik. Bu durumda yapacagm etkinlik her g̈jrencim icin esit sekilde}

Şekil 1. Öğretmenlerin etnomatematik etkinliklerin dezavantajlarına yönelik görüşleri

Etkinliklerin uygulanma sürecinin hem eğlenceli hem de öğretici olduğu ayrıca öğrencilerin derse yönelik ilgilerinin ve derse katılımlarının yüksek olduğu araştırmacı alan notlarında yer almıştır (Şekil 2).

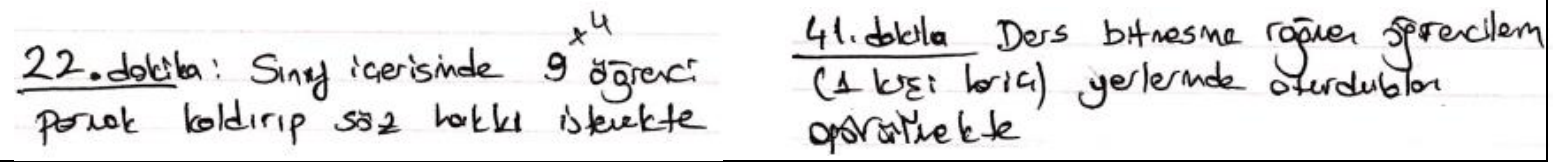

Şekil 2. Araştırmacı alan notlarından örnekler

Uygulanan etkinliklerin değerlendirilmesi amacıyla UÖA'nın ve öğretmenlerin $\mathrm{F}_{4}$ 'te yer alan (1 ile 10 puan arasında cevap verilen) sorulara verdiği cevaplara yönelik ortalama puanlar Tablo 8'de gösterilmiştir.

Tablo 8. Uygulanan etkinlikler ve verimliliklerine yönelik ortalama puanlar

\begin{tabular}{lcc}
\hline Uygulanan etkinliğin verimliliğini değerlendiriniz. (1-10 puan) & Ort. UÖA & Ort. Öğr. \\
\hline Matematiksel kavram/konu öğretimi açısından & 7.67 & 7 \\
\hline Kültür aktarımı açısından & 10 & 10 \\
\hline Öğrencilerin matematik öğrenimi açısından & 8.34 & 7 \\
\hline Sinıf yönetimi açısından & 5.34 & 7 \\
\hline Öğrencilerin derse ilgisi açısından & 8.67 & 8.5 \\
\hline Sizin etkinliğe yaklaşımınız açısından & 9 & 7 \\
\hline
\end{tabular}

Etnomatematik etkinliklerinin verimliliğini değerlendiren UÖA ve öğretmenler, en yüksek puanı etkinliklerin kültür aktarımı noktasında verirken en düşük puanı ise sınıf yönetimi açısından vermişlerdir. Öğretmenler değerlendirmelerde sınıf yönetimi açısından UÖA'dan daha fazla puan verirken diğer noktalarda UÖA'dan daha az puan vermişlerdir. Etkinliklerin verimliliğine yönelik yapılan açıklamalarda ise öğrencilerin kültürel ögeleri öğrendikleri ve ilgilerini artırdıkları ifade edilmiştir. Bununla birlikte kalabalık sınıflarda etkinlikleri uygulamanın zorluğu ve uygulama sürecindeki beklenmedik durumlar gibi sınıf yönetiminde yaşanan sorunlar dile getirilmiştir (Şekil 3).

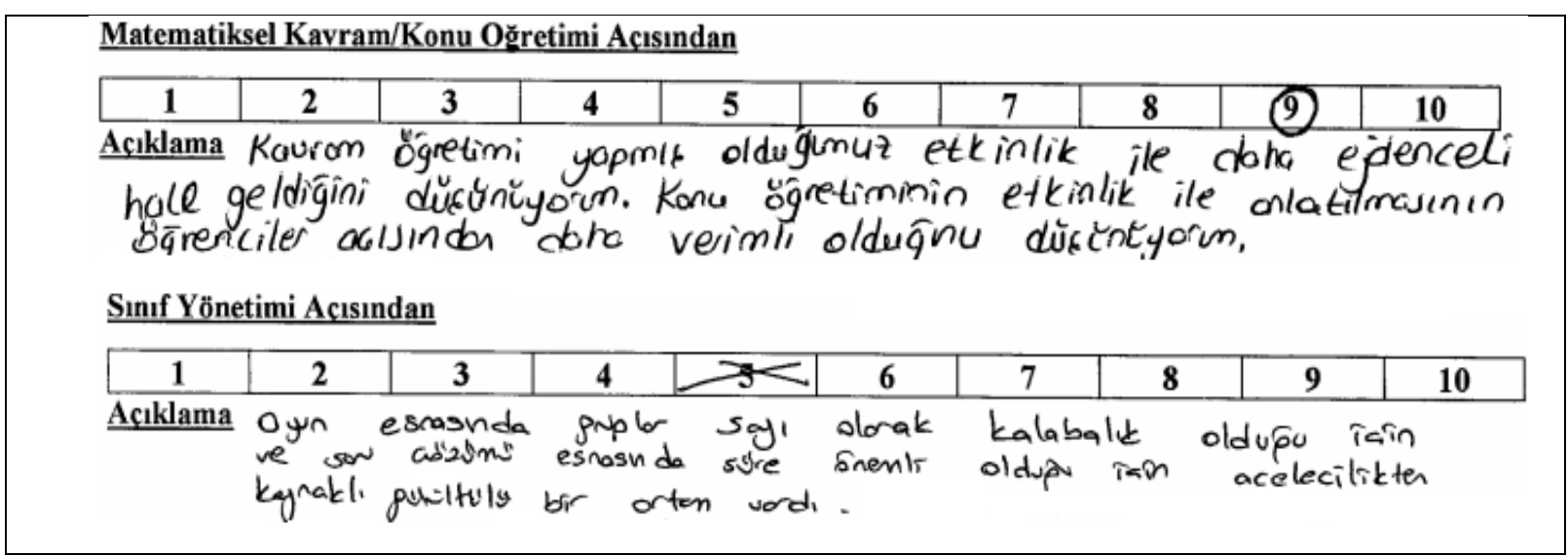

Şekil 3. Öğretmen adaylarının uygulanan etkinliklerin verimliliğine yönelik ifadeleri

Yapılan görüşmelerde $\mathrm{UÖA}_{1}$ ve UÖA $\mathrm{U}_{2}$ etkinlik uygulama sürecinin avantajları olduğunu ifade etmiş ve sınıf hâkimiyeti konusunda sorun yaşadıklarını aktarmıştır. Örneğin, UÖ $A_{1}$ etkinlik sürecinde oyun kurallarına uyma noktasında sorun çıkaran öğrenciler olmasından dolayı sınıf hâkimiyetini sağlayamadığını, UÖA 2 ise dersin bazı bölümlerinde öğrencilerin gürültü oluşturmasını engelleyemediğini belirtmişlerdir.

$U \ddot{O} A_{1}:$... Öğrencilerin kültürel şeyleri öğrenmek istemeyeceklerini ve sıkılacaklarını düşünmüştüm... Gruplara ayırma süreci gerçekleştikten sonra etkinliği anlatınca bir gördüm ki sınıf çok eğleniyor. Ders o kadar 
güzel geçti ki hem matematik hem kültür, ikisini aynı anda farkında olmadan öğrendiler. Ben de kültürel etkinlik uygulamanin önemli olduğunu ögrendim...

A: Peki bu sürecin olumsuz yanları var mıydl senin için?

$U{ }_{U} A_{1}$ : Aslında vardı sinı hâkimiyeti. Öğrencilerimi bazen durduramadım. Oyun sürecinde kuralları esnetmeye çalışan öğrenciler oldu tepkisiz kaldım.

$U O ̈ A_{2}:$ Ögrrencilerin ders ile ilgilenmediği kısımlarda sessizliği oluşturamadım ...

\subsection{Farkındalık, Önceki Öğrenme ve Mesleki Hayatta Kullanıma Yönelik Bulgular}

Öğretmen adayları ve öğretmenlerin matematik ve kültür arasındaki ilişkiye yönelik farkındalıklarının belirlenmesi amacıyla hazırlık aşaması öncesi ve uygulama aşaması sonrasında $F_{1}$ uygulanmıştır. Hazırlık aşaması öncesinde 6 tane TÖA, 2 tane UÖA ile $\ddot{O}_{2}$ matematik ve kültürün ilişkili olduğunu belirtmiştir. Uygulama aşaması sonrasında ise dikkat çekici bir bulgu ortaya çıkmış ve öğretmen adaylarının ve öğretmenlerin tamamı matematik ve kültürün ilişkili olduğunu belirtmişlerdir (Tablo 9).

Tablo 9. Kültür ve matematik arasındaki ilişkiye yönelik ifadelerin analizi

\begin{tabular}{|c|c|c|c|c|}
\hline İlişki & Hazırlık Aşaması Öncesi & TÖA & UÖA & Öğretmen \\
\hline \multirow{2}{*}{ Vardır } & Matematik tarihi ve bilim adamlarının varlığ 1 & 6 & 2 & 0 \\
\hline & Eski yapılarda ve halı motiflerinde matematik vardır. & 0 & 0 & 1 \\
\hline \multirow{2}{*}{ Yoktur } & $\begin{array}{l}\text { Matematik kurallar ve formüllerden oluşur. Kültür ise } \\
\text { toplumsal hayatı etkiler. }\end{array}$ & 12 & 4 & 1 \\
\hline & $\begin{array}{l}\text { Matematik formüller, Kültür ise gelenek-görenekler ile } \\
\text { iliş̧kilidir. }\end{array}$ & 4 & 0 & 0 \\
\hline İlişki & Uygulama Sonrası & TÖA & UÖA & Öğretmen \\
\hline \multirow{4}{*}{ Vardır } & $\begin{array}{l}(\mathbf{M} \rightarrow \mathbf{K}) \\
\text { Kültürümüzde bulunan birçok ögenin oluşumunda } \\
\text { matematik kullanılmıştır. } \\
\text { Matematik kültürü aktarmada araçtır. }\end{array}$ & 7 & 3 & 0 \\
\hline & $\begin{array}{l}(\mathbf{K} \rightarrow \mathbf{M}) \\
\text { Matematiksel kavramların ortaya çıkışında kültür önemli } \\
\text { bir yere sahiptir. } \\
\text { Matematiğin gelişimi kültürden etkilenmiştir. }\end{array}$ & 10 & 2 & 0 \\
\hline & $\begin{array}{l}(\mathbf{M} \leftarrow \rightarrow \mathbf{K}) \\
\text { Matematik ve kültür karş1lıkl etkileşim halindedir. }\end{array}$ & 3 & 1 & 2 \\
\hline & Günlük hayatın her alanında matematik vardır. & 2 & 0 & 0 \\
\hline
\end{tabular}

Hazırlık aşaması öncesinde, öğretmen adaylarının büyük çoğunluğu $(n=20)$ ve $\mathrm{O}_{1}$ matematiğin kurallar ve formüller ile kesin ve değiştirilemez gerçeklerden oluştuğunu, kültürün ise bireyin ve toplumların geçmişi ve tarihi ile ilişkili olduğunu ifade etmişler ve bu nedenle matematik ve kültürün ilişkili olmadığını belirtmişlerdir. Geriye kalan öğretmen adayları $(\mathrm{n}=8)$ ile $\mathrm{O}_{2}$ ise matematik tarihine vurgu yaparak ve eski zamanlarda yapılmış evlerde ve halı motiflerinde matematik olduğunu belirterek, matematik ve kültürün ilişkili olduğunu ifade etmişlerdir.

Uygulama sonrasında ise öğretmen adayı ve öğretmenler matematik ve kültür ilişkisini dört düşünceye dayandırarak açıklamışlardır. Bunlardan ilk üçü matematik ve kültürün birbirini sıralı ya da çift yönlü etkilediği (matematiğin kültürü etkilediği $[\mathrm{M} \rightarrow \mathrm{K}]$, kültürün matematiği etkilediği $[\mathrm{K} \rightarrow \mathrm{M}]$ ve matematik ve kültürün çift taraflı birbirini etkilediği $[\mathrm{M} \leftarrow \rightarrow \mathrm{K}]$ ) düşünceleri iken son düşünce ise günlük hayatın her alanında matematik olduğudur. $\mathrm{M} \rightarrow \mathrm{K}$ ilişkisinde, kültürün oluşumunda ve aktarılmasında matematik aracı olmaktadır. $\mathrm{K} \rightarrow \mathrm{M}$ ilişsisinde ise matematiksel kavramların ortaya çıkışını ve matematiğin gelişimini kültür etkilemektedir. $\mathrm{M} \leftarrow \rightarrow \mathrm{K}$ ilişkisi ise kültür ve matematiğin karşılıklı olarak birbirini etkiledikleri dinamik bir süreci ifade etmektedir.

Hazırlık aşaması sonrasında etnomatematik ile ilgili önceki öğrenmelerini belirlemek amacıyla öğretmen adayları ve öğretmenlere $F_{2}$ uygulanmıştır. Öğretmen adaylarının 5 tanesi önceki eğitim-öğretim süreçlerinde etnomatematik ile ilişkili öğretim ortamında bulunduklarını ifade etmişlerdir. Bu adaylar lisans dönemi I. yarıyılda aldıkları matematik tarihi dersini $(\mathrm{n}=2)$, ortaokulda katıldıkları müze gezisini $(\mathrm{n}=2)$ ve İstanbul Miniatürk gezisini örnek göstermişlerdir. Öğretmen adayları bu tecrübelerinin yeterli olmadığını hem yazılı görüş formlarında hem de görüşmelerde ifade etmişlerdir. Öğretmenler ise derslerinde etnomatematik ortam oluşturma amacında olmadıklarını fakat bazı zamanlarda konu ve kavrama yönelik matematik tarihi hakkında bilgi verdiklerini ifade etmişlerdir.

$T \ddot{A} A_{2}$ : ...Özellikle daha önce bir kez müzeye gitmiştim ama çok çok farkll şekilde matematik ve kültürün ortak noktası olabilirmiş. 
A: Peki, lise döneminde yaptı̆̆ınız müze gezisi kültür ve matematik ilişkisini görmek açısından yeterli midir?

TÖA $A_{2}$ : Asla yeterli değil. Çok çok farklı bir ilişki varmıs matematik ve kültür arasında. Biz sadece bu ilişki hakkında minik bir şey yapmışız

Önceki öğrenmelerinde etnomatematik ile karşılaşmayan öğretmen adayları etnomatematik ile ilişkili öğrenme ortamlarında bulunmama nedenlerini öğretmen merkezli eğitim, öğretim programı yetişme zorunluluğu ve öğretmenlerin etnomatematik hakkındaki bilgi eksikliği olarak ifade etmişlerdir. Bu durumun olası sonuçlarını ise, matematiğe yönelik bakış açılarının tek yönlü olması ve matematiğin ortaya çıkış sürecini ve kültürümüz ile ilişkisini öğrenememe olarak belirtilmişlerdir. Örneğin uygulama öncesinde $\mathrm{UÖA}_{1}$, matematik ve kültürün çok farklı alanlar olduğunu düşündüğünü, TÖA $A_{1}$ ise matematiğin kültürden ayrı kurallar, yöntemler ile soru çözümleri yapılan bir alan olduğunu ifade etmiştir. Ayrıca TÖA 1 , öğretmenlerin bu konuda bilgi eksikliği yaşadıklarını ve aldığı ders ve tasarlama süreci ile bu eksikliği yaşamayacağını belirtmiştir.

$U \ddot{O} A_{1}$ : .... Aslında bugüne kadar nasıl olur da böyle etkinlikleri hiç ögrenememişim o çok garip geldi bana. Hatta dönem başında matematik ve kültürün apayrı olduğunu düşünüyordum. Aslında bu düşüncemi hatırladıkça gülüyorum kendime. Belki de öğrenmediğim için uygulamayı çok daha fazla istiyorum...

TÖA $A_{1}$ : ... Matematik derslerinde böyle matematikle ilgisiz görünen kültürel şeylerin kullanılabiliyor olması çok ilginç. Daha doğrusu ben öğrenciyken hiç böyle matematik görmedim. Hep kurallar, yöntemler ve test soruları çözdüm. Ama bu şekilde Kanaviçe kullanarak, Bindallı kullanarak, Cami yaparak, Zeybek oynayarak matematik öğrenmek çok iyi olurdu. Bu konuda kendimi eksik hissediyorum...

$T \mathrm{O}_{1}$ : ... Bence öğretmenlerimin bu konular hakkında çok bilgisinin olmamast. Çünkü ben böyle bir ders almasaydım belki ben de bilmeyecektim. Bu etkinliği tasarlamasaydım kullanabileceğimi düşünmeyecektim.

Öğretmen adayları ve öğretmenlerin tamamı mesleki hayatlarında etnomatematik etkinliklerini kullanacaklarını ifade etmişler ve bu düşüncelerini Tablo 10'da yer alan açıklamaları ile desteklemişlerdir.

Tablo 10. Etnomatematik etkinliklerinin mesleki hayatta kullanılmasına ilişkin görüşler

\begin{tabular}{|c|c|c|c|c|}
\hline Kategori & Kod Örnekleri & TÖA & Ü̈A & Öğretmen \\
\hline $\begin{array}{l}\text { Matematiğe } \\
\text { Bakış }\end{array}$ & $\begin{array}{l}\text { Matematiğe yönelik bakış açısı değişir. } \\
\text { Matematiğin formül ve kural dışında uygulama alanı görülür. } \\
\text { Ön yargılar yıkılabilir. }\end{array}$ & 12 & 5 & 2 \\
\hline Ders Süreci & $\begin{array}{l}\text { Derse olan ilgi artar. } \\
\text { Motivasyonu artırır. } \\
\text { Eğlenceli hale gelir. }\end{array}$ & 21 & 6 & 1 \\
\hline $\begin{array}{l}\text { Matematik } \\
\text { ve Kültür }\end{array}$ & $\begin{array}{l}\text { Matematik ve kültür arasındaki ilişki öğrenilir. } \\
\text { Kültürümüzü öğrenebilirler. } \\
\text { Kültürel ögelere yönelik farkındalık oluşturur. }\end{array}$ & 14 & 5 & 2 \\
\hline
\end{tabular}

Öğretmen adayları etnomatematik etkinliklerini mesleki hayatlarında kullanma nedenlerini etkinliklerin öğrencilerin matematiğe yönelik bakış açısını değiştirebilmesi $(n=17)$, matematik-kültür ilişkisini görebilmelerini sağlaması $(n=19)$ ve ders sürecine olumlu etki yapabilmesi $(n=27)$ şeklinde ifade etmişlerdir (Şekil 4).

A: ... Peki bu tarz etkinlikleri meslek hayatınızda kullanmayı düşünüyor musun?

TÖ $A_{1}$ : Kesinlikle düşünüyorum. Derste yaptı̆̆ımız etkinliklerin hepsini kullanacă̆ım...

$T \ddot{O A} A_{2}$ : Tabi ki düşünüyorum. Çünkü kendi tasarladığımız etkinlikte matematik öğrenme korkusu olmadan ögrrenmeye başlayabiliriz. Matematik için çok gerekli bence, çünkü ögrenciler çok çok korkuyor.

$U \ddot{O A} A_{2}$ : Uygulamayı düşünüyorum. Birçok etkinlik oluşturduk. Bunlarl bilgisayarıma yedekledim. Araştırmaya da devam edeceğim başka etkinlikler olabilir mi diye.

$\ddot{O}_{2}$ : Uygulayabileceğimi fark ettim. Öğrencilerin derse ilgisi, motivasyonu istenilen düzeye çıabilir. Ayrıca ögrencilerin kültürü ögrenebilmeleri, matematik ile ilişkisini görmeleri açısından faydall.

$\ddot{O}_{1}$ :Derslerimde kullanacă̆ım. Öğrencilerimin matematiğin işlem ve formül olmayan yüzünü görmeleri için bir firsat olur. 


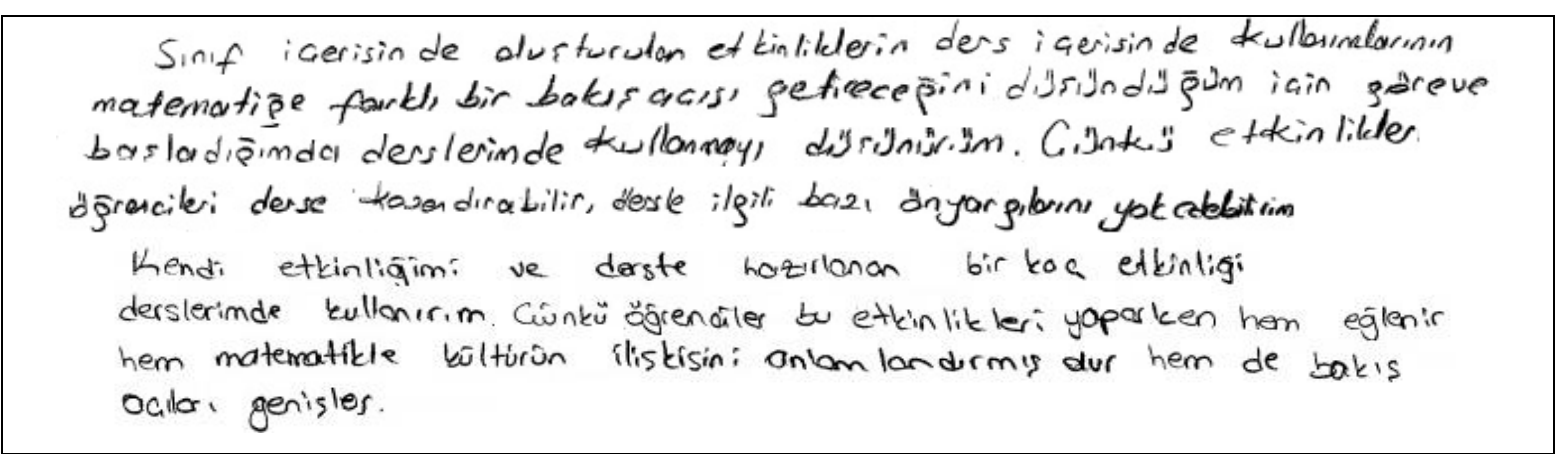

Şekil 4. Etnomatematik etkinliklerin mesleki hayatta kullanılmasına ilişkin öğretmen adayı görüşleri

\section{3. Öğrencilerin Uygulama Sürecini Değerlendirmesine Yönelik Bulgular}

Etnomatematik etkinlikleri uygulanan sınıflardaki öğrencilerin tamamı $(n=71)$ önceki matematik derslerinde kültür ile ilgili etkinlik yapmadıklarını ifade etmiştir. Öğrencilerin 62 tanesi bundan sonraki matematik derslerinde kültürümüz ile ilişkili benzer etkinlikler yapmak istediklerini belirtirken; 9 tanesi ise bu etkinliklerin yapılmasını istememiştir. Etkinliklerin yapılmasını isteyen öğrenciler açıklamalarında etkinliklerin eğlenceli olduğunu ve bu etkinlikler ile matematik ve kültürümüze ait bilgileri öğrendiklerini vurgulamışlardır (a ve b maddesi, Şekil 5). Etkinliklerin derslerde yapılmamasını isteyen öğrenciler ise açıklamalarında derste gürültü olduğunu ve derste matematik işlenmediğini belirtmişlerdir (Şekil 5 c maddesi).

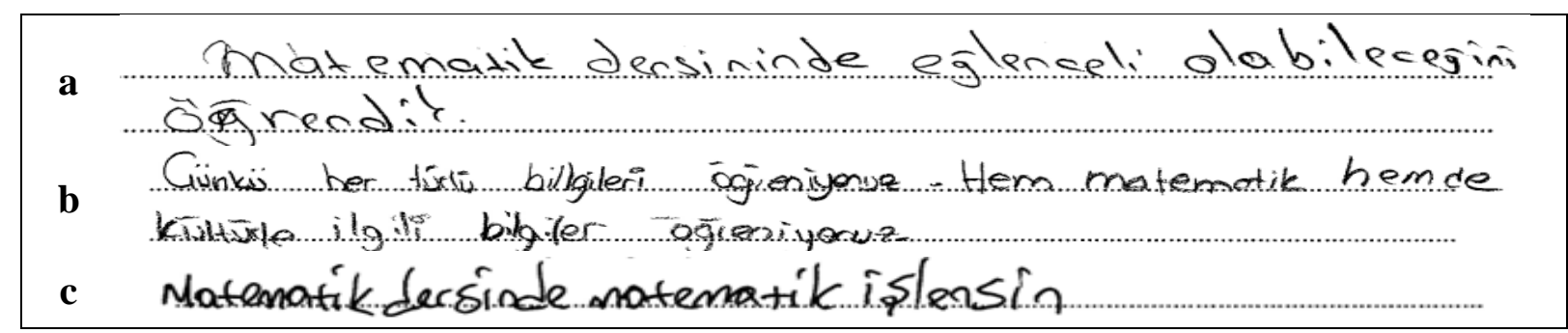

Şekil 5. Etnomatematik etkinliklere yönelik öğrenci ifadeleri

Uygulama sürecinin öğrenci boyutunda değerlendirilmesi amacıyla sorulan "Bu etkinliğe 1 ile 10 arasında kaç puan verirsiniz” sorusuna öğrencilerin ortalama 9.14 puan verdiği görülmüştür. Ayrıca öğrencilerin "Etkinlik sayesinde neler öğrendiniz" sorusuna verdikleri cevaplar Tablo 11'de belirtilmiştir.

Tablo 11. Öğrencilerin etkinlikler yardımıyla öğrenmelerine ilişkin görüşleri

\begin{tabular}{llc}
\hline Kategori & Kod Örnekleri & f \\
\hline \multirow{2}{*}{ Kültür } & Kültürümüze ilişkin bilgiler öğrendim. & 59 \\
\cline { 2 - 3 } & Kenaviçe yapımını öğrendim. & 21 \\
\hline \multirow{3}{*}{ Matematik } & Kareköklü sayılarla ilgili soru çözümleri öğrendim. & 19 \\
\cline { 2 - 3 } & Dönüşüm geometrisi konularını öğrendim. & 21 \\
\cline { 2 - 3 } & Denklemler konusunu hatırladım. & 11 \\
\cline { 2 - 3 } & Grafik çizmeyi hatırladım. & 7 \\
\hline
\end{tabular}

Öğrenciler etkinlikler yardımıyla kültürümüze ilişkin bilgileri $(n=59)$ ve kanaviçeyi ( $n=21)$, ve ayrıca kareköklü sayılar $(n=19)$, dönüşüm geometrisi $(n=21)$, denklemler $(n=11)$ ve grafik çizme (n=7) gibi matematiksel konu ve kavramları öğrendiklerini ifade etmişlerdir.

Öğrenciler "Etkinlik ile ilişkili önerileriniz ya da görüşleriniz var mıdır?" sorusuna ise genellikle olumlu cevaplar vermişler $(n=29)$ ve farklı zamanlarda yine bu tarz etkinlikler yapmak istediklerini belirtmişlerdir (Şekil 6a-6b). Ayrıca bazı öğrenciler $(n=7)$ etkinlikte yer alan soruların sayısının ve çeşidinin artması gerektiğini çünkü sınavlarda daha zorlayıcı sorular sorulduğunu ifade etmişlerdir (Şekil 6c). Dört öğrenci ise etkinliklerin gereksiz olduğunu ve matematik derslerinde kullanılmaması gerektiğini belirtmişlerdir (Şekil 6d). Bu öğrencilerin matematik derslerinde etkinlik yapılmasını istemeyen öğrenciler olduğu görülmüsstür. Geriye kalan 21 öğrenci ise herhangi bir açıklama yapmamıştır. 


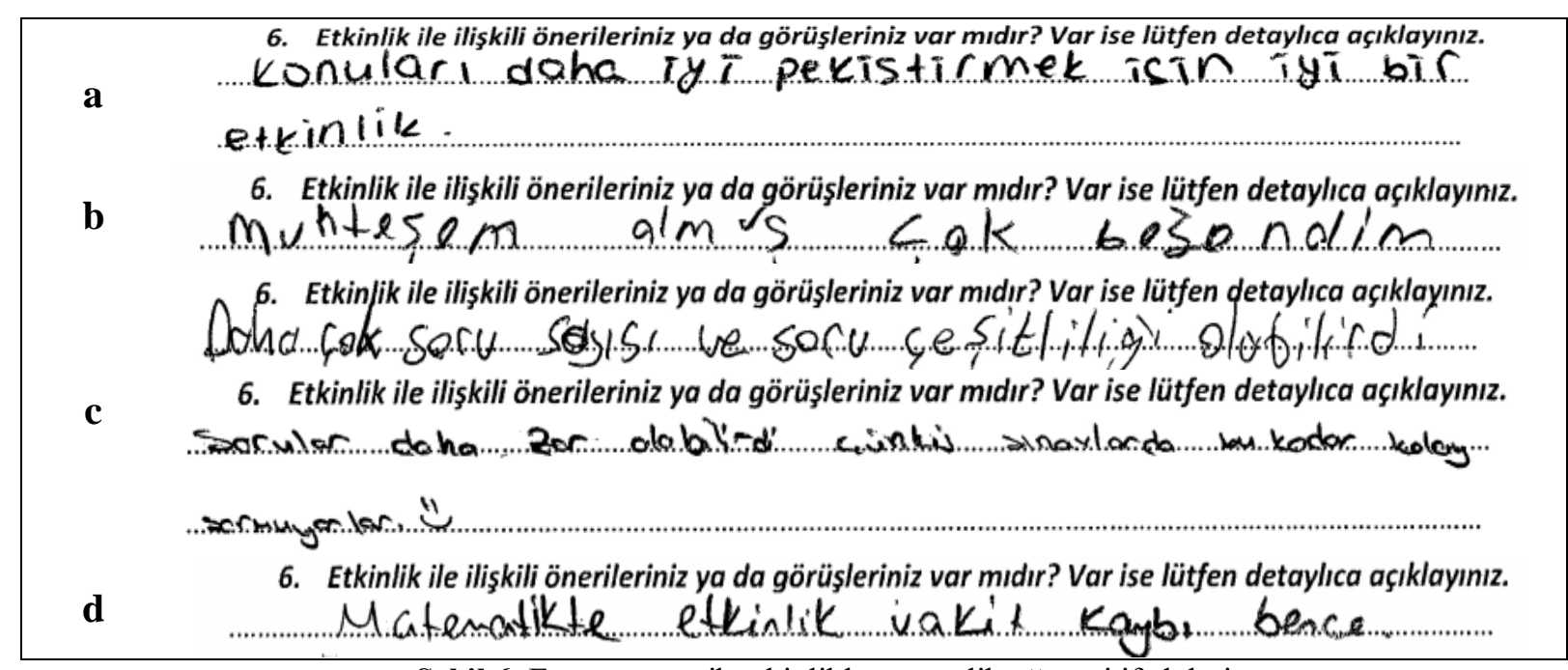

Şekil 6. Etnomatematik etkinliklere yönelik öğrenci ifadeleri

\section{Tartışma ve Sonuç}

$\mathrm{Bu}$ araştırmada, etnomatematik etkinliklerin ilköğretim matematik öğretmen adayları tarafından tasarlanmasının öğretmen adayı boyutunda, tasarlanan etkinliklerin sınıf ortamında uygulanmasının öğretmen adayı, öğrenci ve öğretmen boyutlarında incelenmesi ve ilköğretim matematik öğretmen adayları ve öğretmenlerin etnomatematiğe yönelik farkındalık, önceki öğrenme ve mesleki hayatta kullanım durumlarının belirlenmesi amaçlanmıştır. Bu amaç doğrultusunda ilköğretim matematik öğretmen adayları tarafından dokuz tane etnomatematik etkinlikleri tasarlanmış, tasarlanan etkinliklerden iki tanesi sınıf ortamında uygulanmıştır. Öğretmen adaylarının teorik bilgi ile donanımının yanında okul ortamında uygulamalar yapmaları ve deneyimler kazanmaları gerekmektedir (Ayas, 2009). Bu gereklilik düşünüldüğünde teorik olarak tasarlanan etkinliklerin uygulama sürecine yansımalarının görülmesi teori ve uygulamanın birlikte ele alınması açısından önemlidir.

Tasarlanan etkinliklerin genellikle geometri öğrenme alanı ile ilişkili olmasının, kültürel ögelerde geometrik kavramlara sıklıkla rastlanılması (Snipes ve Moses, 2001) ve kültürümüzde yer alan halı motiflerinde, figürlerde, cami süslemeleri ve yöresel kıyafetlerde geometrik şekillerin fazlaca yer almasından kaynaklandığ düşünülebilir. Öğretmen adayları web tabanlı aramalar ile ya da çeşitli sosyal medya uygulamalarını kullanarak yaptıkları araştırmalarda bu kültürel ögeler ile sıklıkla karşılaşmışlardır. Ayrıca geometri öğrenme alanı dışındaki etkinliklerden biri olan Mangala etkinliğinin seçiminin de Mangala oyununun web tabanlı aramalarda ilk sırada çıkması nedeniyle öğretmen adayı araştırmaları ile ilişkili olduğu düşünülebilir (Zaslavsky, 1998). Tasarlanan etkinliklerin önceki öğrenmeler ile ilişkilendirilmesi ise matematik dersi öğretim programının sarmal bir yapıda ilerlemesi nedeniyle etkinliklerin güçlü bir yönü olarak kabul edilebilir. Farklı konulara yönelik etkinliklerin olmaması ise etnomatematik alanında kısıtlı kaynaklara ulaşılmasının ve var olan kaynakların da tam anlamıyla yeterli olmadı̆̆ının bir sonucu olarak görülebilir. Nitekim etnomatematik alanında yapılan çalışmaların azlığı ve kaynak kitapların sayısının yetersiz olması, öğretmen adaylarının etkinlik tasarlama sürecinde etkinliğe karar verirken zorlanmalarına da neden olmuştur. Ayrıca öğretmen adaylarının henüz lisans seviyesi 3. döneminde öğrenim görmelerinden kaynaklı olarak öğretim programı ve pedagoji bilgilerinin yeteri kadar gelişmemiş olması etkinlik tasarlama sürecinde zorlanmalarına neden olmuş olabilir. Bununla birlikte öğretmen adaylarının Zeybek oyununu profesyonel düzeyde oynaması ve GeoGebra programını iyi derecede kullanması gibi bireysel özellikleri de etkinliğe karar verme sürecinde belirleyici olmuştur.

Etkinlik tasarlama süreci, öğretmen adaylarının tecrübe edinmelerini sağlamış; kültürel ögelere yönelik bilgilerini ve kültür-matematik ilişkisine yönelik farkındalığını artırmış; öğretmen adaylarına kültürel bir ögeyi matematik derslerinde kullanabilme düşüncesini ve matematik dersi öğretim programı bilgisini kazandırmıştır. $\mathrm{Bu}$ durum, etkinlik tasarlama sürecinin öğretmen adaylarının genel kültür, pedagojik ve pedagojik alan bilgilerine yönelik olumlu katkılar sağladığını gösterebilir. Öğretmen adaylarının etnomatematik ile ilişkili etkinlik tasarlamalarının onların mesleki gelişimlerine katkıda bulunabileceği düşünülmektedir. Ayrıca bu süreçte öğretmen adayları grup çalışmasının önemli olduğunu vurgulamışlardır. Bu durum, grupla çalışma, grup içerisinde fikir alışverişinde bulunma, bu esnada grup üyelerinin fikrine saygı duyup aynı zamanda bireysel düşünceleri de savunabilme becerilerinin etnomatematik yaklaşım için önem arz ettiği ve grup çalışmasının önemle üzerinde durulması (Kelly, 2005) fikirlerini de desteklemektedir. Bununla birlikte öğretmen adaylarının etkinlik tasarlama sürecinin olumsuz etkisinin ve zararının olmadığını ifade etmeleri de araştırmada amaca uygun bir çalışma grubu seçildiğinin bir göstergesi olmuştur. 
Tasarlanan etkinliklerden seçilen Kanaviçe ile İç İçe etkinliği konu anlatım sürecinde, MatKül etkinliği ise konu değerlendirme sürecinde kullanılmıştır. Etkinliklerin uygulama sürecinde göze çarpan en önemli yansımalarından birisi öğrencilerin derse katılımlarının ve ilgilerinin artması olmuştur. $\mathrm{Bu}$ sınıflarda (Öğretmenlik Uygulaması I dersi kapsamında) ders gözlemi ve ders anlatımı yapan stajyer öğretmen adaylarının önceki derslere göre belirgin farklılıklar olduğunu ifade etmeleri, etnomatematik etkinliklerinin sınıf içerisinde kullanımının önemli ve faydalı (Spines ve Moses, 2001) olduğunun göstergesi olarak düşünülebilir. Öğretmenler de etkinliklerin derse ilgiyi artırdığını ve matematiğe yönelik tutumu olumlu yönde etkilediğini ifade etmişlerdir. Bu durumu, öğrencilerin etkinliklere verdikleri puanların ortalamasının yüksek olması ve etkinliklere yönelik olumlu ifadeleri de desteklemektedir. Bu sonuçlar ile etnomatematik etkinliklerinin uygulanmasının öğrencilerde matematiğe yönelik olumlu tutum oluşturduğu (Aktuna, 2013; Kara, 2009) düşüncesi ifade edilebilir. Ayrıca etkinlikler kültür aktarımı noktasında öğretmen adayı ve öğretmenlerden tam puan almışlardır. Bununla birlikte etnomatematik etkinlikler ile öğrencilerin kültürümüze ilişkin bilgi sahibi olmaları ve kültürel ögeleri merak etmeye başlamaları da öğretmen adaylarının ve öğretmenlerin avantaj olarak nitelendirdiği ders sürecindeki olumlu yansımalardır.

Etkinliklerin matematik konularının öğretiminde ve öğreniminde de etkili olduğu öğretmen adayları ve öğretmenler tarafindan vurgulanmıştır. Bu vurgulanan düşünce, etnomatematiğin başarıyı artıran (Magallanes, 2003), matematiksel anlama yeteneğini geliştiren (Widada ve ark., 2018) ve matematiksel düşünme becerilerini geliştiren (Iluno ve Taylor, 2013; Powell ve Temple, 2001) bir alan olduğu düşüncesini de desteklemektedir. Öğretmen adaylarının matematik öğretimi ve öğrenimi noktasında öğretmenlere kıyasla daha yüksek puanlı değerlendirmelerde bulunmaları da etnomatematiğe bakış açıları ile açıklanabilir. Öğretmen adaylarının etkinliklere yaklaşımları noktasında öğretmenlerden daha yüksek değerlendirme yapmaları da bu durumu desteklemektedir. Tabi ki bu durum öğretmen gözünden bakıldığında bütüncül bir öğretim programı bilgisi ve anlatılacak konuların uygunluğu, kazandırılması gereken hedef davranışlar, beklentiler, sınav sistemi gibi hususlar göz önüne alındığında daha farklı değerlendirilebilir. Bazı öğrencilerin etnomatematik etkinliklerine yönelik olumsuz ifadeleri de öğrencilerin öğrenim yöntemi, istekleri, matematiğe yönelik inançları gibi bireysel özellikleri ile ilişkili olabilir. Çünkü etnomatematik etkinliklerinin ders süreçlerinde kullanılmasının gerekli olmadığını ifade eden öğrenciler aynı zamanda matematik derslerinde etkinlik yapılmasına da karşı çıkmışlardır.

Etnomatematik etkinliklerin uygulanması sürecinde yaşanan en büyük sorun sınıf yönetimi noktasındadır. Bu durum etkinlik uygulama sürecinde karşlaşılan doğal bir sorun olmakla (Şahin ve Eraslan, 2019) birlikte öğretmen adaylarının henüz tecrübe eksikliği ile de açıklanabilir. Öğretmenlerin sınıf yönetimi açısından dersi

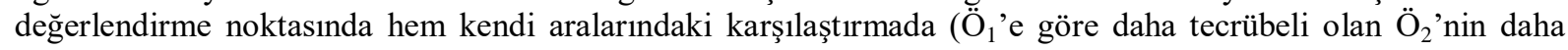
yüksek puan vermesi) hem de öğretmen adaylarından daha yüksek puan vermesi artan tecrübe ile sinıf yönetiminin sağlanabileceğinin göstergesi olarak görülebilir. Bu durum aynı zamanda sınıf yönetiminin zamanla kazanılabilecek bir beceri olduğunu ve etnomatematik etkinlikleri için dezavantaj olarak görülmemesi gerekliliğini de göstermektedir. Tüm bu düşünceler ışığında araştırma amacına uygun olarak etnomatematik etkinliklerinin hem kültür aktarımında hem matematik ögretiminde hem de matematiğe yönelik tutumda olumlu etki oluşturduğu görülmektedir. Bu sonucu öğrenci açıklamaları ve araştırmacı alan notları da desteklemektedir.

Öğrencilerin önceki derslerinde kültür ve matematik ile ilişkili benzer etkinliklere yer verilmediğini ifade etmesi, öğretmen adaylarının da benzer şekilde düşüncelere sahip olması ve öğretmenlerin de ders anlatım süreçlerinde etnomatematiği kullanmamaları tutarlılık göstermiştir. $\mathrm{Bu}$ durum matematik derslerinde etnomatematiğin neredeyse hiç kullanılmadığını göstermektedir ki alanyazın da bunu desteklemektedir (D’Ambrosio ve Rosa, 2017; Kang, 1992). Etnomatematiğin önemi düşünüldüğünde, matematik derslerinde (bu çalışmadaki gibi) etnomatematik temelli ders süreçlerinin artırılması bir gereklilik (Shirley, 2001; Presmeg, 1998) olarak görülmelidir. Bu gereklilik her ne kadar MEB (2018) ve YÖK (2018) tarafindan ortaya konulsa da öğretim programlarında kazanımların öğretimi boyutunda eksiklikler bulunmaktadır. Bu durumun en büyük engellerinden biri de öğretmenlerin etnomatematiğe hazır olmamasıdır (Lewis, 2016) ki öğretmen adaylarının bu anlamda eğitimi araştırma açısından güçlü bir nokta olmuştur. Öğrencilerin bundan sonraki derslerde benzer etkinliklerin yapılmasını istemesi ve hatta etkinliklerde soru çeşidinin ve sayısının artırılması gibi katılımcı bir düşünceye sahip olmaları sonraki matematik derslerinde benzer etkinliklerin kullanılması bağlamında önemli bir bulgudur. Etnomatematik etkinliklerin sınıf ortamında kullanımının artması ile öğrenciler kendi kültürleri ile matematik dersi arasında etkileşim olduğu düşüncesini kazanabilir (Bishop, 1994; Zaslavsky, 1998). Bu düşüncenin oluşumu d'Entremont, (2015) ve Krummel (2013) tarafindan vurgulanan öğretim eksikliğini de ortadan kaldıracaktır. Ayrıca böylelikle kültürel bakış açıları ile öğretim programları oluşturulabilir (Mukhopadhyay ve Greer, 2013; Rosa ve Orey, 2011).

Araştırmanın ortaya koyduğu önemli sonuçlardan bir tanesi de öğretmen adayı ve öğretmenlerin etnomatematik farkındalığını arttırmasıdır. Araştırma öncesinde kültür ve matematik arasında ilişki olmadığından ya da temel düzeyde ilişki olduğundan bahsetmişlerdir. Bu durum sınıf ortamlarında matematiğin akademik olması ve öğretim programlarının kültürel ögelerle ilişkilendirilmemesinden kaynaklanabilir (D’Ambrosio, 2001). Araştırma sonunda ise öğretmen adayları ve öğretmenler matematik ve kültür arasında 
$M \rightarrow K, K \rightarrow M$ ve $M \leftarrow \rightarrow K$ şeklinde tek yönlü ya da karşıllklı ilişki olduğunu ifade etmişlerdir ki bu durum etnomatematik etkinliklerinin tasarlanmasının ve sınıf ortamında uygulanmasının öğretmenlerin ve öğretmen adaylarının kültür ile matematik ilişkisine yönelik farkındalıklarını artırdığını göstermiştir. Öğretmenlerin ve öğretmen adaylarının kendi kültürleri ile matematiğin ilişkili olduğunu deneyimleyerek öğrenmeleri etnomatematiğin önemli amaçlarından biri olan kültüre değer verme (D’Ambrosio ve Rosa, 2017) amacına da ulaşıldığını göstermektedir. Buradan hareketle matematik ve kültür arasındaki ilişkinin yapılacak araştırmalar ve düzenlenebilecek öğrenme ortamları ile rahatça aktarılabileceği sonucuna ulaşılmıştır.

Araştırma sürecinde öğretmen adayları ve öğretmenlerin matematik ve kültür ilişkisinin farkındalığının artmasının yanında matematiğe yönelik bakış açılarının da değiştiği görülmüş̧ür. Öğretmen adayları matematiğin formül ve kuralların dışında uygulamaya yönelik bir yönünün olduğunu ve kültürümüzde sıklıkla yer aldığını fark etmiş̧lerdir. Bu durum matematiğin doğasının anlaşılmasını (Barta, 2001) ve matematik niçin kullanılır, matematik hayatımızın neresinde gibi klişe olarak görülen fakat cevabı çok derinlere inmeyen sorular için yeni cevapların geliştirilmesini sağlayacaktır. Ayrıca kültürel öğeler içeren matematik öğretim programları uygulandığında öğrenciler üzerinde anlamlı etkiler oluşturduğu, programdaki bu kültürel öğelerin öğrencilerin matematiği anlamalarını derinleştirerek, matematiği gündelik hayatlarının bir parçası olarak görmelerine ve böylece anlamlı bağlantılar geliştirmelerine katkıda bulunduğu görülmüştür (Bishop, 1994; Stathopoulou, 2017; Zaslavsky, 2002). Etnomatematik ile öğretim programları ve ders planları öğrencilerin kültürel çevrelerine uygun olarak tasarlandığında bunun matematiğin günlük hayatta kullanıldığının bir göstergesi olacağı söylenebilir.

\section{5. Öneriler}

Araştırmanın başında öğretmen adaylarının birbirleri ile ilişkili matematik ve kültür alanları hakkındaki eksik ya da hatalı bilgileri matematik eğitimi açısından düşündürücüdür. Çünkü kültür ve matematik arasındaki ilişki etnomatematiğin doğasını açılamaktadır (D'Ambrosio, 2001). Etnomatematiğin önemi düşünüldüğünde bu araştırmaya benzer çalışmaların yürütülmesi bu noktada önem kazanmaktadır. Ayrıca öğretim programlarında her ne kadar vurgu yapılsa da sınıf ortamında anlatılan matematik derslerinin etnomatematikten bağımsız olduğu araştırma sürecinde ortaya çıkmıştır. Bu durumun iyileştirilmesi için öğretmenlerin ve öğretmen adaylarının etnomatematik farkındalıklarının artırılması önerilebilir. Öğretmenler ve öğretmen adayları kültürel ögeleri matematik dersinde kullanmaya istekli olsa da bunu nasıl gerçekleştireceklerine yönelik materyal, rehber eksikliği görülmektedir. Bu bağlamda matematik dersi öğretim programı hazırlanırken konuların kültür ile ilişkisinin kurulacağı ve öğretmenlerin derslerinde kullanabilecekleri bu araştırmada tasarlanan etkinliklere benzer etkinliklerin tasarlanıp, kullanılabileceği araştırmaların yapılması önerilebilir. Ayrıca bu araştırmada tasarlanan etkinliklere benzer etkinliklerin yer aldığ 1 öğretim süreçleri oluşturulup, öğretmen ve öğrenciler ile görüşmeler gerçekleştirilerek öğretim süreçleri başarı, motivasyon, tutum, kaygı gibi değişkenler ile ilişkilendirilip detaylı değerlendirmelerde bulunulabilir.

Etik Kurul Onay Bilgileri: Araştırma ile ilgili Sakarya Üniversitesi, Sosyal ve Beşeri Bilimler Etik Kurulu'ndan 18/03/2020 tarih ve E.3607 sayı, 21 no'lu karar ile etik kurul uygunluk onayı alınmıştır (Bk. detaylar) 
Etkinlik Adı: MatKüL

\section{Ek 1}

Öğrenme Alanı: Sayılar ve İşlemler

Alt Öğrenme Alanı: Kareköklü İfadeler

Etkinlik amacı:

- Ortaokul Matematik öğretim programında yer alan Kareköklü İfadelere yönelik kazanımlara ilişkin soru çözümü yapılması,

- Kültürümüze yönelik ögeler hakkında bilgilendirme yapılması

- Matematik tarihindeki önemli bilim adamlarının tanıtılması

Süre: 40 dakika

Sinıf: 8. Sinif

Öğrenci Sayısı: 24

Uygulama Şekli: Grup Çalışması (8 Kişilik)

Uygulama Süreci: Sekiz kişiden oluşan gruplar ve grup liderleri yuvarlak masa etrafina dizilir. Her bir grupta dörder kişilik iki takım oluşturulur. Oluşturulan gruplardan zar atması istenir... Çarkın sarı ucunun gösterdiği sayının karşısındaki bilim adamı hakkında kısa bilgilendirme grup lideri tarafından yapılır. Bilgilendirme sonrasında gelen sayı pozitif ise oyuna başlanır... Oyunun başlaması ardından her bir adımın altında yazan kültüre yönelik kısa bilgilendirme yazısı okunur. Kum saati ile birlikte belirlenen süre sonunda grubun cevabı istenir. Kültürel ögelere verilecek her doğru cevap negatif sayı gelen bir atışın tekrarlanması hakkı, toplamda beş doğru cevap ise bir adım ilerleme hakkını verecektir...Kültür sorusuna verilecek cevabın ardından okun geldiği renge ait sorular içerisinden rasgele bir matematik sorusu grup üyeleri tarafindan seçilerek grubun çözmesi istenir ...

\section{Matematik Sorularından Örnekler}

- $\sqrt{5-x}$ ifadesinin irrasyonel olabilmesi için $\mathrm{x}$ yerine kaç tane tane doğal sayı gelebilir?

- Bir kenarı $\sqrt{180} \mathrm{~cm}$ diğer kenarı $\sqrt{128} \mathrm{~cm}$ olan dikdörtgenin çevresinin uzunluğunu hesaplayını.

- $\quad \sqrt{29}$ ile $\sqrt{101}$ arasındaki doğal sayılardan kaç tanesi çifttir?

\section{Kültür Sorusundan Örnekler}

- Genellikle Ramazan aylarında iftardan sonra eğlenme amaçlı perdeye yansitılan oyunumuzdur. Oyun içerisinde iki başrol vardir.

- $\quad$ Tiğg, iğne gibi araçlarla, genellikle beyaz pamuklu iplikle zincir çekilerek ya da iğne ile çeşitli düğümler atılarak oluşturulan bir örgü türüdür.

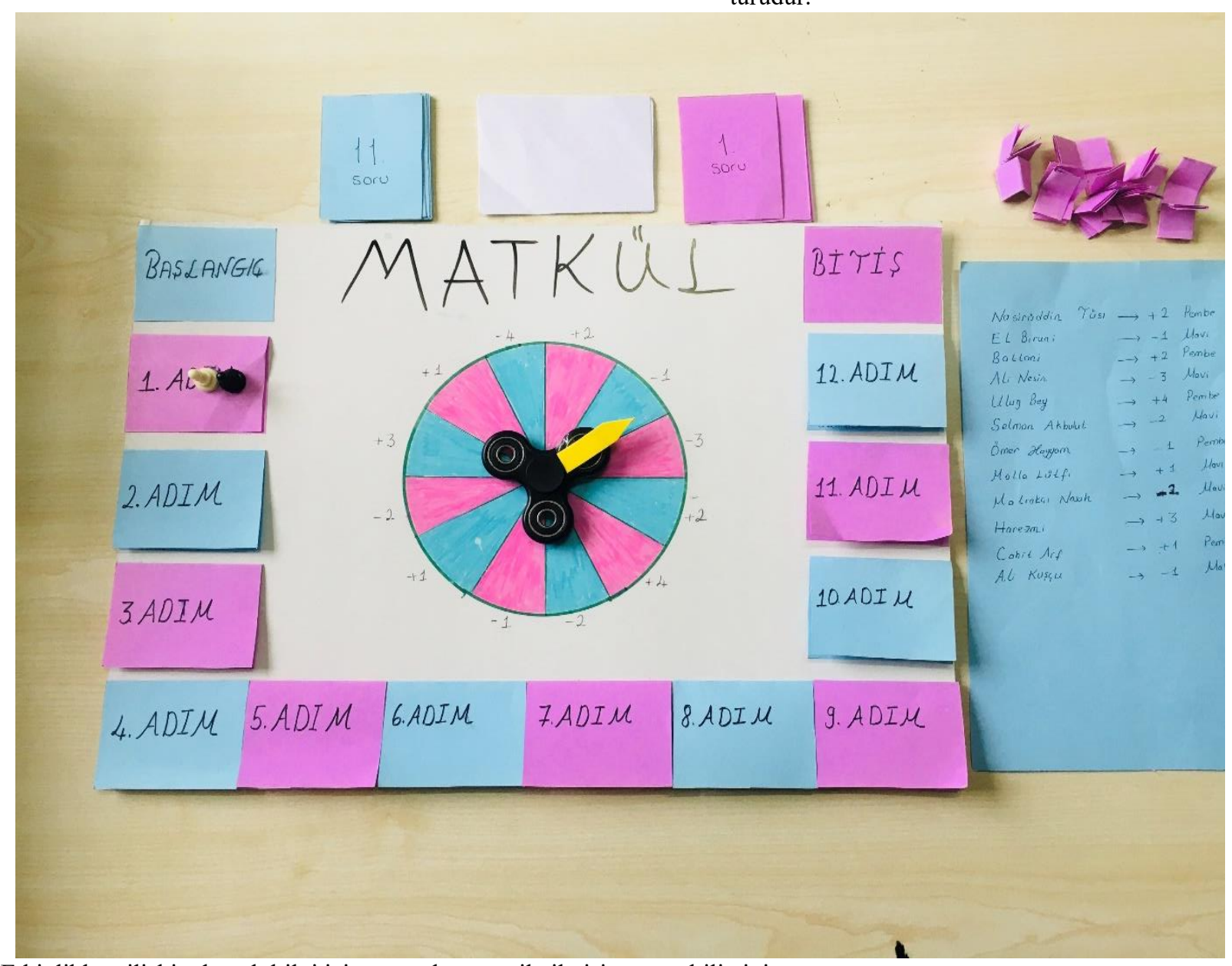

Etkinliklere ilişkin detaylı bilgi için sorumlu yazar ile iletişime geçebilirsiniz. 


\section{Ek 2}

Etkinlik Adı: Kanaviçe ile İç İçe

Öğrenme Alanı: Geometri

Alt Öğrenme Alanı Dönüşüm Geometrisi

Etkinlik amacı:

- Ortaokul Matematik Uygulamaları öğretim programında yer alan "MU.8.3.2.1. Dönüşüm geometrisinin uygulama alanlarını belirler.” Kazanımının öğretilmesi,

- Kültürümüzde yer alan Kanaviçe'nin tanıtımı, Kanaviçe yapımının gösterimi

Süre: 80 dakika

Sinıf: 8. Sinıf

Öğrenci Sayısı: 28

Uygulama Şekli: Bireysel/Grup Çalışması (2-3 Kişilik)

Uygulama Süreci: Kanaviçe örnekleri tüm öğrencilere inceletilir. Sonrasında, Kanaviçe nedir?, Kanaviçe hakkında bir bilginiz var mı?, Daha önce kanaviçe gördünüz mü?, Evinizde kanaviçe var mı?, Büyüklerinizden kanaviçe işleyen tanıdığınız var mı?, Kanaviçe nasıl yapılır? soruları yöneltilir. Ardından ise getirilen A3 boyutundaki çizimler öğrencilere dağıtılır ve öğrenciler inceler. Öğrencilerden gördükleri çizimlerin özelliklerini yorumlamaları ve bu yorumların tahtaya sekreter öğrenci tarafından yazılması istenir. Öğrenciler basitten karmaşığa aşamalı bir şekilde bu kanaviçe çizimlerini oluşturmaya başlar. İlk aşamada öğrencilerden aşağıda tamamlanmış kanaviçeyi incelemeleri istenir. İkinci aşamada yarısı verilmiş kanaviçenin diğer yarısının y- eksenine göre simetrisi alınarak tamamlanması istenir. Üçüncü aşamada bir bölümü verilmiş kanaviçe çizimini öteleme ile tamamlanması istenir. Dördüncü aşamada son olarak boş kareli A3 kağıdına öğrenciler serbest çalışma yaparak istenilen kanaviçeyi istediği yöntemle çizer.

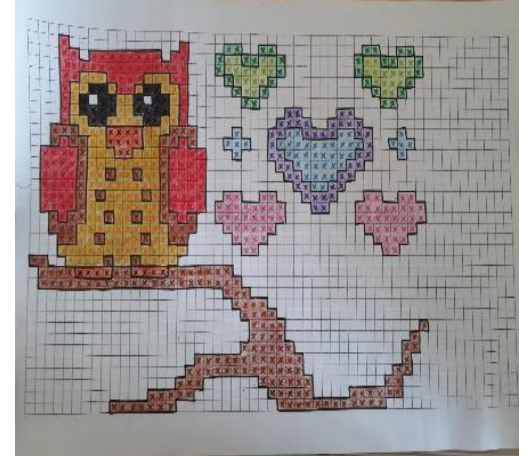

Aşama 1

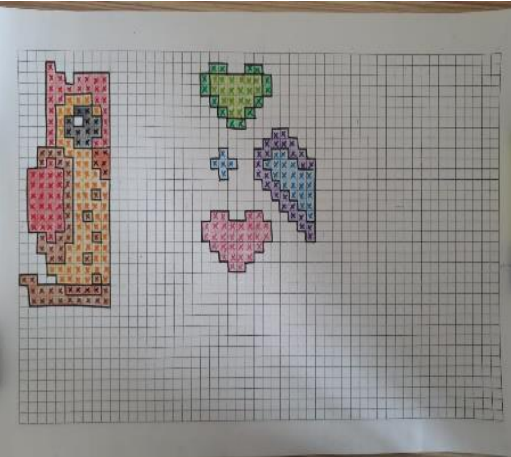

Așama 2

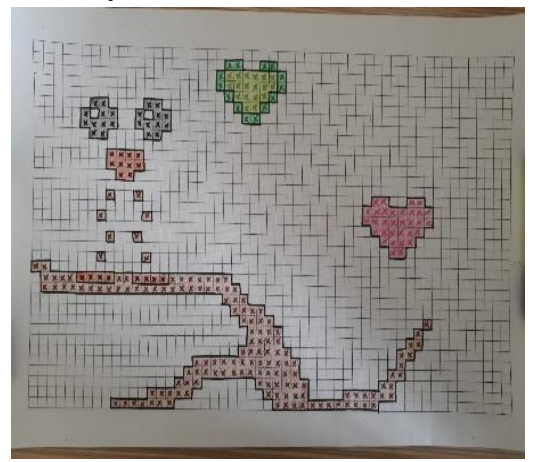

Așama 3

Etkinliğin sonunda öğrencilere değerlendirme soruları dağıtılır ve öğrenciler tarafindan bu sorular çözülür.

\section{Değerlendirme Sorularından Örnekler}

- Bünyamin Amca baykuş kanaviçesinde 3 ilmek için $4 \mathrm{~cm}$ ip kullanıyorsa yapmak istediğimiz kanaviçenin elde edilmesi için gereken ip miktarı ne kadardır? (Bu soruda farklı kısımları eksik bırakılan kanaviçe deseni için gerekli ip miktarı kastedilmektedir. Baykuş kanaviçesi= 672 ilmek)

- Kullanılan ip miktarını renklerine göre sıralayıp bu veri grubunun açıklığını bulunuz.

- Kanaviçe deseninin tamamlanması için kullanılan iplerin renklerine göre miktarları arasında oransal ilişki varsa yazınız.

Öğrencilere desenli kanaviçe yapımı (aşağıda) ev ödevi olarak verilir.

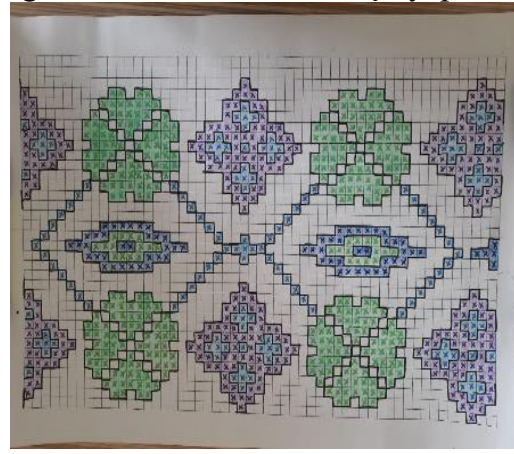

Aşama 1

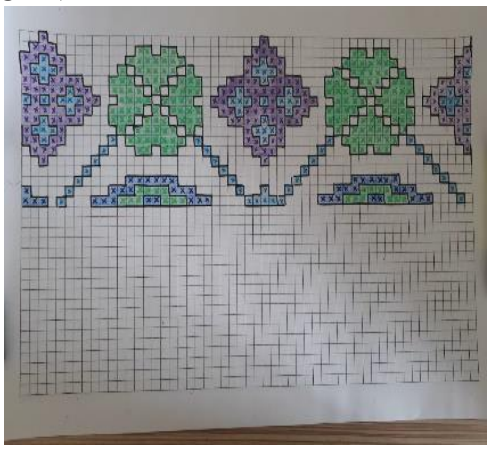

Aşama 2

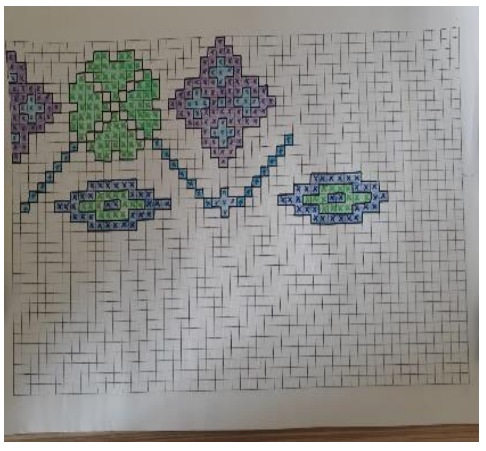

Așama 3

Etkinliklere ilișkin detaylı bilgi için sorumlu yazar ile iletişime geçebilirsiniz. 


\section{Kaynaklar / References}

Adam, S. (2004). Ethnomathematical ideas in the curriculum. Mathematics Education Research Journal, 16(2), 49-68.

Aktuna, H. E. (2013). Sixth grade students' perceptions of and engagement in ethnomathematical tasks in the area measurement concept (Unpublished master's thesis). Middle East Technical University, Institute of Social Sciences, Ankara.

Ascher, M. (1994). Ethnomathematics: A multicultural view of mathematical ideas. New York: CRC Press.

Ayas, A. (2009). The importance of teaching profession and current problems in teacher training. Inonu University Journal of The Faculty of Education, 10(3), 1-11.

Baki, A. (2014). Matematik tarihi ve felsefesi. Ankara: Pegem Akademi.

Barta, J. (2001). By way of introduction: Mathematics and culture. Teaching Children Mathematics, 7(6), 305311.

Barton, B. (1996). Making sense of ethnomathematics: Ethnomathematics is making sense. Educational Studies in Mathematics, 31, 201-233.

Bishop, A. (1994). Cultural conflicts in mathematics education: Developing a research agenda. For the Learning of Mathematics, 14(2), 15-18.

Bishop, A. J. (1991). Mathematical enculturation: Perspective on mathematics education. Netherlands: Kluwer Academic Publishers.

D'Ambrosio, U. (2001). What is ethnomathematics, and how can it help children in schools? Teaching Children Mathematics, 7, 308-310.

d'Entremont, Y. (2015). Linking mathematics, culture and community. Procedia-Social and Behavioral Sciences, 174, 2818-2824.

D’Ambrosio, U. (2007). Ethnomathematics: Perspectives. North American Study Group on Ethnomathematics News, 2(1), 2-3.

D'Ambrosio, U. (2018). The program ethnomathematics: Cognitive, anthropological, historic and socio-cultural bases. PNA-Revista de Investigación en Didáctica de la Matemática, 12(4), 229-247.

D’Ambrosio, U., \& Rosa, M. (2017). Ethnomathematics and its pedagogical action. In M. Rosa, L. Shirley, M. E. Gavarrete, \& W. V. Alangui (Eds.), Ethnomathematics and its diverse approaches for mathematics education (pp. 285-305). Hamburg: Springer.

Ercan, B. (2005). Etnomatematik: Yeni bir disiplinin ortaya çıkışına bir örnek. Matematik Dünyası, 3, $106-107$.

Francois, K., \& Van Kerkhove, B. (2010). Ethnomathematics and the philosophy of mathematics (education). In B. Lowe, \& T. Muller (Eds.), Philosophy of mathematics: Sociological aspects and mathematical practice (pp. 121-154). London: College Publications.

Gerdes, P. (1994). Reflections on ethnomathematics. For the Learning of Mathematics, 14(2), 19-22.

Gerdes, P. (2001). Ethnomathematics as a new research field, illustraties by studies of mathematical ideas in African history. In J. J. Saldana (Ed.), Science and cultural diversity: Filling a gap in the history of science (pp. 11-36). México: Sociedad Latinoamericana de Historia de las Ciencias y la Tecnología.

Güreş, H. (2019). Farklı kültürel değerlere sahip ortaokul 7. sınıf öğrencilerin matematiksel düşüncelerinin incelenmesi: Bir Etnomatematik uygulaması (Yayımlanmamış yüksek lisans tezi). Anadolu Üniversitesi, Eğitim Bilimleri Enstitüsü, Eskişehir.

Iluno, C., \& Taylor, J. I. (2013). Ethnomathematics: The key to optimizing learning and teaching of mathematics. IOSR Journal of Research \& Method in Education (IOSR-JRME), 3(1), 53-57.

Kang, H. (1992). Stakeholders' treceptiveness to an ethnomathematics curriculum foundation: The case of Cameroon (Unpublished doctoral dissertation). The University of British Columbia, Canada.

Kara, M. (2009). Effects of instructional design integrated with ethnomathematics: Attitudes and achievement. (Unpublished master's thesis). Boğaziçi University, Institute of Graduate Studies in Science and Engineering, İstanbul.

Kelly, A. J. (2005). The design and evaluation of strategies to implement ethnomathematics into secondary mathematics classes in the United States based on an examination of ethnomathematics in practice: A mixed design study (Unpublished doctoral dissertation). University of Denver, the USA.

Krummel, A. (2013). Multicultural teaching models to educate pre-service teachers: Reflections, servicelearning, and mentoring. Current Issues in Education, 16(1). Retrieved January 12, 2020 from https://cie.asu.edu/ojs/index.php/cieatasu/article/view/1059.

Leitze, R. A. (1997). Connecting process problem solving to children's literature. Teaching Children Mathematics, 3(7), 398-405.

Lewis, K. C. (2016). Ethnomathematics meets history of mathematics: A case study (Unpublished master's thesis). Texas A \& M University, the USA.

Lim, C. S., \& Ernest, P. (1997, March). Values in mathematics education: What is planned and what is espoused? Paper presented at the Conference of British Society for Research into Learning Mathematics (BSRLM), Nottingham, UK.

Lincoln, Y. S., \& Guba, E. G. (1985). Naturalistic Inquiry. Newbury Park, CA: Sage Publications. 
Magallanes, A. M. (2003). Comparison of student test scores in a coordinate plane unit using traditional classroom techniques versus traditional techniques coupled with ethnomathematics software at Torch middle school (Unpublished master's thesis). National University, the USA.

Milli Eğitim Bakanlığı [MEB]. (2018). Matematik dersi ögretim programı (ilkokul ve ortaokul 1, 2, 3, 4, 5, 6, 7 ve 8. siniflar). Ankara: MEB.

Mukhopadhyay, S., \& Greer, B. (2013, January). Can ethnomathematics enrich mathematics education?. Paper presented at Fifth International Conference to Review Research on Science, Technology and Mathematics Education, Mumbai, India. Abstract retrieved from http://episteme.hbcse.tifr.res.in/index.php/episteme5/5/paper/view/176/42.

Patton, M. Q. (1990). How to use qualitative methods in evaluation. London: Sage Publications.

Powell, A., \& Temple, O. (2001). Seeding ethnomathematics with "aware": Sankofa. Teaching Children Mathematics, 7(6), 369-375.

Presmeg, N. (1998). Ethnomathematics in teacher education. Journal of Mathematics Teacher Education, 1(3), 317-339.

Rosa, M., \& Orey, D. C. (2010). Ethnomodeling: A pedagogical action for uncovering ethnomathematical practices. Journal of Mathematical Modelling and Application, 1(3), 58-67.

Şahin, N., \& Eraslan, A. (2019). Middle-school prospective mathematics teachers' opinions on the use of modeling activities at the course of mathematics applications. Turkish Journal of Computer and Mathematics Education (TURCOMAT), 10(2), 373-393.

Sevgi, S. (2019). Dönüşüm geometrisi etkinliklerine kültürel bağlamın dâhil edilmesi sonucu oluşan öğrenci yaklaşımları (Yayımlanmamış yüksek lisans tezi). Dokuz Eylül Üniversitesi, Eğitim Bilimleri Enstitüsü, İzmir.

Shirley, L. (2001). Ethnomathematics as a fundamental of instructional methodology. ZDM - Zentralblatt für Didaktik der Mathematik, 33(3), 85-87.

Snipes, V., \& Moses, P. (2001). Linking mathematics and culture to teach geometry concepts. LTM Journal Louisiana Association of Teacher of Mathematics, 1(1), 1-17. Retrieved December 20, 2019 from www.lamath.org/journal/Vol1/LinkCult

Stathopoulou, C. (2017). Once upon a time... The gypsy boy turned 15 while still in the first grade. In M. Rosa, L. Shirley, M. E. Gavarrete, \& W. V. Alangui (Eds.), Ethnomathematics and its diverse approaches for mathematics education (pp. 97-123). Cham, Switzerland: Springer.

Stathopoulou, C., Kotarinou, P., \& Appelbaum, P. (2015). Ethnomathematical research and drama in education techniques: Developing a dialogue in a geometry class of $10^{\text {th }}$ grade students. Revista Latinoamericana de Etnomatemática, 8(2), 105-135.

Widada, W., Herawaty, D., \& Lubis, A. N. M. T. (2018). Realistic mathematics learning based on the ethnomathematics in Bengkulu to improve students' cognitive level. Journal of Physics: Conference Series, 1088, 1-8.

Yıldırım, A. ve Şimsek, H. (2013). Sosyal bilimlerde nitel araştırma yöntemleri (9. genişletilmiş baskı). Ankara: Seçkin Yayıncılık.

Yılmaz, N., Öztürk, T., \& Kanbolat, O. (2012, Haziran). Bir etnomatematik uygulamasından yansımalar. X. Ulusal Fen ve Matematik Eğitimi Kongresi’nde sunulan bildiri, Niğde Üniversitesi, Niğde.

Yin, R. (1994). Case study research: Design and methods. Second Thousand Oaks, CA: Sage.

Yüksek Öğretim Kurulu [YÖK]. (2018). İlköğretim matematik ögretmenliği lisans programı. Ankara: Ankara Üniversitesi Basımevi.

Zaslavsky, C. (1998). Ethnomathematics and multicultural mathematics education. Teaching Children Mathematics, 4(9), 502-503.

Zaslavsky, C. (2002). Exploring world cultures in math class. Educational Leadership, 60(2), 66-69. 